University of Nebraska - Lincoln

DigitalCommons@University of Nebraska - Lincoln

Daugherty Water for Food Global Institute:

Faculty Publications

Daugherty Water for Food Global Institute

2021

Transmission Routes of the Microbiome and Resistome from

Manure to Soil and Lettuce

Yuepeng Sun

Daniel D. Snow

Harkamal Walia

Xu Li

Follow this and additional works at: https://digitalcommons.unl.edu/wffdocs

Part of the Environmental Health and Protection Commons, Environmental Monitoring Commons, Hydraulic Engineering Commons, Hydrology Commons, Natural Resource Economics Commons, Natural Resources and Conservation Commons, Natural Resources Management and Policy Commons, Sustainability Commons, and the Water Resource Management Commons

This Article is brought to you for free and open access by the Daugherty Water for Food Global Institute at DigitalCommons@University of Nebraska - Lincoln. It has been accepted for inclusion in Daugherty Water for Food Global Institute: Faculty Publications by an authorized administrator of DigitalCommons@University of Nebraska Lincoln. 


\title{
Transmission Routes of the Microbiome and Resistome from Manure to Soil and Lettuce
}

\author{
Yuepeng Sun, ${ }^{1}$ Daniel Snow, ${ }^{2}$ Harkamal Walia, ${ }^{3}$ and $\mathrm{Xu} \mathrm{Li}^{4}$ \\ 1 Department of Civil and Environmental Engineering, University of Nebraska- \\ Lincoln, Lincoln, Nebraska 68588, United States \\ 2 Nebraska Water Center, University of Nebraska-Lincoln, Lincoln, Nebraska \\ 68588, United States \\ 3 Department of Agronomy and Horticulture, University of Nebraska-Lincoln, \\ Lincoln, Nebraska 68583, United States \\ 4 Department of Civil and Environmental Engineering, University of Nebraska- \\ Lincoln, Lincoln, Nebraska 68588, United States
}

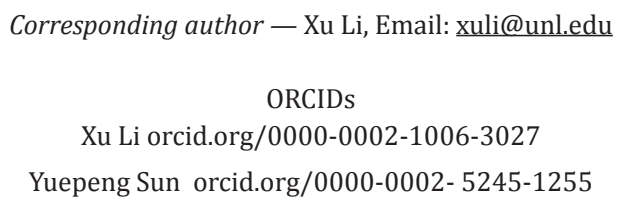

\begin{abstract}
The land application of animal manure can introduce manure microbiome and resistome to croplands where food crops are grown. The objective of this study was to characterize the microbiome and resistome on and in the leaves of lettuce grown in manured soil and identify the main transmission routes of microbes and antibiotic resistance genes (ARGs) from soil to the episphere and endosphere of lettuce. Shotgun metagenomic results show that manure application significantly altered the composition of the microbiome and resistome of surface soil. SourceTracker analyses indicate that manure and original soil were the main source of the microbiome and resistome of the surface soil and rhizosphere soil, respectively. Manure application altered the microbiome and resistome in the episphere of lettuce (ADONIS $p<0.05$ ), and surface soil accounted for $\sim 81 \%$ of the microbes and $\sim 62 \%$ of the ARGs in episphere. Manure application had limited impacts on the microbiome and resistome in the endosphere (ADONIS $p>0.05$ ). Our results show that manure-borne microbes and ARGs reached
\end{abstract}

Published in Environmental Science and Technology 55 (2021), pp. 11102-11112.

doi:10.1021/acs.est.1c02985

Copyright (C) 2021 American Chemical Society. Used by permission.

Submitted 10 May 2021; revised 17 July 2021; accepted 19 July 2021; published 29 July 2021. 
the episphere primarily through surface soil and some epiphytic microbes and ARGs further entered the endosphere. Our findings can inform the development of pre- and postharvest practices to minimize the transmission of manure-borne resistome from food crops to consumers.

Keywords: microbiome, resistome, transmission, manure, soil, lettuce

\section{Introduction}

Livestock manure and poultry litter are often applied to croplands as a soil amendment to increase crop yields. ${ }^{1}$ While this practice reduces the need of synthetic fertilizers, it also leads to potential risk of introducing fecal bacteria carrying antibiotic resistance genes (ARGs) to soil and crop. For leafy green vegetables that are eaten raw, studies have shown that bacteria associated with both the endosphere (in leaf) and the episphere (on leaf) may survive food processing and get ingested by consumers. ${ }^{2}$ Hence, leafy vegetables have been considered a potential vector of transmitting ARGs from the environment to the human diet. ${ }^{3}$

Using quantitative polymerase chain reaction (qPCR), studies have reported that land application of manure can increase the diversity and abundance of ARGs in soil and vegetables planted in soil, such as endive, ${ }^{4}$ lettuce, ${ }^{5,6}$ carrot, ${ }^{6}$ radish, and tomato. ${ }^{6}$ For example, the abundance of sul 1 gene was 160 -fold greater on the surface of lettuce grown in manureamended soil than on lettuce grown in soil receiving inorganic chemical fertilizers. ${ }^{5}$ Similarly, the abundance of ARGs was 8 -fold higher inside lettuce grown in soil receiving animal manure or manure mixed with crop residues than inside conventionally produced lettuce grown in soil receiving chemical fertilizers. ${ }^{3}$ Hence, manure application can impact the ARGs associated with crops. The US Food Safety Modernization Act requires animal manure to be land applied in a manner that avoids contact with produce or manure must be composted prior to application. ${ }^{7}$ Better understanding about the transmission of the manure-borne microbiome and resistome in the soil-plant ecosystem can help minimize contamination risk.

Recent studies report overlaps of the microbiome and resistome among different compartments of the plant-soil ecosystem, ${ }^{8-12}$ suggesting the possible transmission of microbes and ARGs from soil to plants. For example, overlaps in microbiome have been found between soil and the leaves and flowers of grapevine; ${ }^{12}$ and between the leaf endosphere 
and episphere of Espeletia plant. ${ }^{9}$ In addition, overlaps in the resistome have been discovered between the root of lettuce and soil amended with poultry litter; ${ }^{11}$ between the rhizosphere soil and the phyllosphere of Brassica planted in struvite-amended soil; ${ }^{8}$ and between the rhizosphere soil and the root of mangrove. ${ }^{10}$ These previous studies often investigated a subset of the environmental compartments in the soil-plant ecosystem and focused on either microbiome or resistome. In order to link the potential risk of manure application on the transmission of antibiotic resistance to the general public through vegetable consumption, it is important to characterize both the microbiome and resistome on and in vegetables (i.e., the episphere and endosphere) and determine how manure microbiome and resistome may transmit to the plants through surface soil and rhizosphere soil.

The objective of this study was to characterize the microbiome and resistome on (episphere) and in (endosphere) the leaves of lettuce grown in soil receiving beef cattle manure and identify the main transmission routes of microbes and ARGs from soil to the episphere and endosphere of lettuce. We established the following hypotheses on the transmission of microbiome and resistome to the leaves of a leafy green vegetable following manure application: (1) land application of livestock manure mostly affects the microbiome and resistome of surface soil, not rhizosphere soil; (2) the microbiome and resistome on the surface of lettuce leaves are mostly contributed by surface soil; and (3) the microbiome and resistome inside lettuce leaves are mostly contributed by rhizosphere soil via root. In this study, lettuce was grown in greenhouse under three manure treatment scenarios (i.e., soil receiving no manure or manure equivalent to 5- and 10-year nitrogen needs). DNA was recovered from manure, surface soil of multiple sampling times, rhizosphere soil of multiple sampling depths, root, as well as the episphere and endosphere of lettuce leaves. Shotgun metagenomic approaches were employed to reveal the microbiome and resistome in various sample types under different treatment scenarios. In addition to alpha and beta diversity analyses, the SourceTracker program, which uses a Bayesian approach to estimate the relative contributions from potential sources to a sink environment ${ }^{13}$ based on a probabilistic mixture of the composition of the sources, ${ }^{14}$ was used to determine the role of surface and rhizosphere soil on the lettuce associated microbiome and resistome. The transmission pathways revealed in this study can help guide the development of 
pre- and postharvest practices to minimize the transmission of manureborn resistome from food crops to consumers.

\section{Materials and methods}

\section{Greenhouse Experiments.}

Seeds of leaf lettuce (cultivar Green Salad Bowl, Lactuca sativa) were planted and grown in Rhizoboxes filled with sandy loam (22.5\% silt, $15.0 \%$ clay, $62.5 \%$ sand) soil in a Biosafety Level 2 greenhouse at University of Nebraska-Lincoln. Rhizoboxes were assembled in-house following a published design. ${ }^{15}$ The air temperature was set at $15-18{ }^{\circ} \mathrm{C}$, and the photoperiod was set at $16 \mathrm{~h}$ for lettuce. A preliminary experiment showed comparable weight between lettuce grown in pots and in Rhizoboxes, proving no negative impacts of Rhizobox on lettuce growth. The manure used in the greenhouse experiment was collected in the cattle feedlots at Eastern Nebraska Research and Extension Center in Mead, NE. Clean quartz sand was mixed into a silty clay (60\% of silt and $40 \%$ of clay) from a farm in Lancaster County $\left(40.84^{\circ} \mathrm{N}, 96.66^{\circ} \mathrm{W}\right)$ to make a sandy loam soil, which was used for lettuce growth and was referred to as original soil in this study. Original soil was uniformly packed into each Rhizobox, which was $30 \mathrm{~cm}$ in height, $20 \mathrm{~cm}$ in length, and $5 \mathrm{~cm}$ in width, to a depth of $25 \mathrm{~cm}$.

Greenhouse experiments were conducted under three treatments scenarios (Figure 1): soil receiving no manure $(\mathrm{C})$, soil receiving manure equivalent to 5 -yr nitrogen need (T5, with 4 g manure/year $\times 5$ year $=20$ $\mathrm{g}$, based on manure application rates ranging between $0.34-2.2 \mathrm{~kg}$ dry wt per $\mathrm{m}^{2}$ per year), ${ }^{5,16-18}$ and soil receiving manure equivalent to 10-yr nitrogen needs (T10, with $4 \mathrm{~g}$ manure/year $\times 10$ year $=40 \mathrm{~g}$ ). The manure was broadcast to the surface of the soil. The entire study was replicated three times (i.e., Sep-Dec 2019, Feb- Mar 2020 and Jun-Jul 2020). Within each round, 15 Rhizoboxes were assigned to the three treatment scenarios, 5 Rhizoboxes per scenario. Three rounds resulted in 15 replicate soil-plant model ecosystems ( 5 replicates per round $\times 3$ rounds). Within each round of experiment, the 15 Rhizoboxes were placed randomly on greenhouse benches. The lettuce was watered using an overhead irrigation system with deionized water containing a general purpose 20-10-20 fertilizer by Peters Professional (JR Peters Inc.). Daily 
a

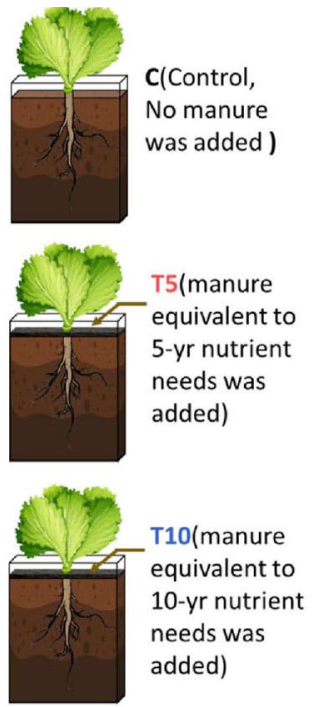

b

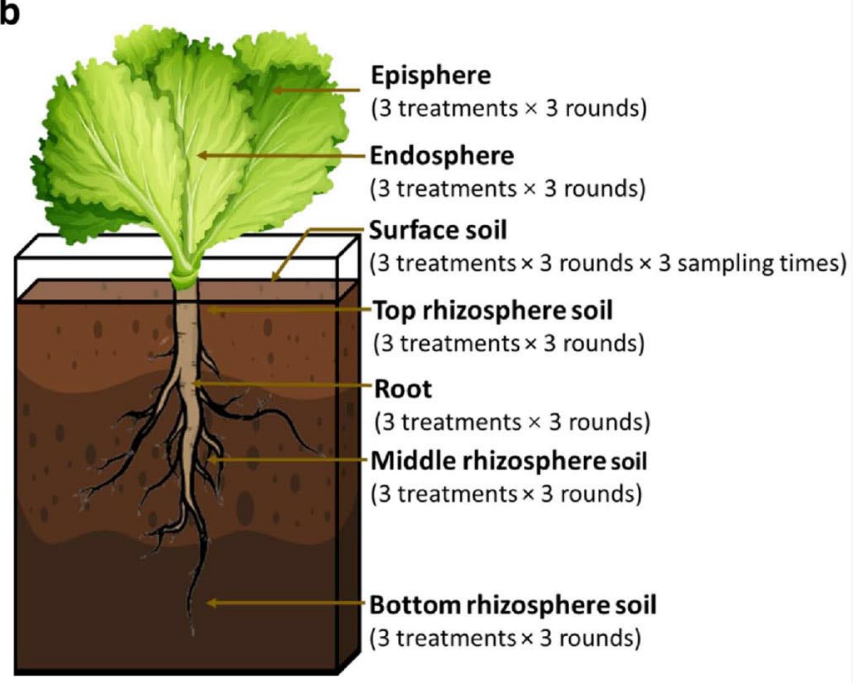

Figure 1. Overview of the experimental design with manure treatment scenarios (a) and sampling strategy (b). Treatment included control (C), manure treatment meeting 5-yr nitrogen needs (T5), and manure treatment meeting 10-yr nitrogen needs (T10). Three rounds of experiments were conducted. Surface soil was sampled at the end of Week 1 , Week 3 , and Week 6 , while the other types of samples were collected only at the end of Week 6 .

irrigation occurred at around $10 \mathrm{am}$. Water was filled about $1 \mathrm{in}$. deep at the top of the rhizosphere box. Water not utilized by the plants drained out of the Rhizosboxes through the holes at the bottom. Seedlings were thinned to 1 plant per Rhizobox at the end of Week 1 when seedlings were 1-2 in. tall. Lettuce was harvested at the end of Week 6.

\section{Sample Collection and Processing.}

Sample types, sampling time and locations are shown in Figure 1 and summarized in Table S1 of the Supporting Information (SI). Leaves of lettuce plants were harvested by cutting below the cotyledonary node at the soil surface using ethanol-sterilized scissors at the end of Week 6. Microbes in the episphere and endosphere of lettuce leaves were separately recovered. For episphere, lettuce leaves were transported into a $50 \mathrm{~mL}$ centrifugal tube with $45 \mathrm{~mL}$ autoclaved phosphate buffered saline (PBS) containing $0.02 \%$ Tween 20 . The solutions were mixed on a vortex mixer for $1 \mathrm{~min}$ and then were shaken at $200 \mathrm{rpm}$ at $30{ }^{\circ} \mathrm{C}$ for 2 $\mathrm{h}$ to recover bacteria from leaf surface. ${ }^{11}$ The washing solution was centrifuged at $2800 \mathrm{rcf}$ for $30 \mathrm{~min}$, and the pellets collected were stored at 
$-20{ }^{\circ} \mathrm{C}$ until DNA extraction. ${ }^{4}$ For the endosphere, the leaf surfaces were sterilized by immersion in 30\% hydrogen peroxide $\left(\mathrm{H}_{2} \mathrm{O}_{2}\right)$ for $1 \mathrm{~min}$ and thoroughly rinsed three times using sterilized water to eliminate the surface bacteria. ${ }^{11}$ The leaf samples were then treated with $70 \%$ ethanol (Ricca Chemical, Arlington, VA) for $1 \mathrm{~min}$ and washed in sterilized water three times. Plant tissues were homogenized in a blender jar containing $100 \mathrm{~mL}$ of sterilized PBS (Sigma-Aldrich, St. Louis, MO) for 30 $\mathrm{s}{ }^{11}$ The solution was centrifuged at $2800 \mathrm{rcf}$ for $30 \mathrm{~min}$, and the pellets collected were stored in $-20{ }^{\circ} \mathrm{C}$ until DNA extraction.

Surface soil (i.e., top 3-4 cm) from each Rhizobox was collected at the end of Weeks 1, 3, and 6. Soil attached to the root were collected as rhizosphere soil samples. ${ }^{19,20}$ After the front panel of Rhizoboxes was opened, rhizosphere soil from different locations of the root zone (top, medium, and bottom) was recovered by cutting the root from these locations. The root segments were transferred to $50 \mathrm{~mL}$ tubes using ethanol-sterilized tweezers. After sterilized PBS was added to the tubes, samples were vortexed for $1 \mathrm{~min}$. After roots were removed, the remaining rhizosphere soil particles were centrifuged for $5 \mathrm{~min}$ at $2800 \mathrm{rcf}$. The pellets were stored at $-20^{\circ} \mathrm{C}$ until DNA extraction. Caution was exercised to avoid surface soil when the rhizosphere soils from the top root zone were recovered.

The roots were sterilized by immersion in $30 \% \mathrm{H}_{2} \mathrm{O}_{2}$ for 30 min to eliminate the bacteria on the surface of roots and washed with sterilized water three times. Samples were then treated with $70 \%$ ethanol for $1 \mathrm{~min}$ and washed in sterilized water 3 times. ${ }^{11}$ Washed roots were homogenized using a blender jar containing $100 \mathrm{~mL}$ of sterilized PBS for $30 \mathrm{~s}^{11}$ After centrifuging at $2800 \mathrm{rcf}$ for $30 \mathrm{~min}$, the root particles collected were used for DNA extraction.

\section{DNA Extraction and Bioinformatics Analysis.}

Microbial DNA in leaf, root, manure, and soil (i.e., original soil, surface soil, and rhizosphere soil) samples was extracted using a DNeasy PowerSoil Kit (Qiagen, Hilden, Germany) according to the manufacturer's instructions. Among samples from each round, DNA was first recovered from five biological replicates and then pooled together in an equal volume fashion to represent the round. There was a total of 27 DNA samples from surface soil (Table S1, 27 samples $=3$ treatments $\times 3$ rounds $\times 3$ sampling times); 27 DNA samples from rhizosphere soil (27 samples $=3$ 
treatments $\times 3$ rounds $\times 3$ sampling locations); 9 DNA samples each from root, episphere, and endosphere ( 9 samples $=3$ treatments $\times 3$ rounds).

Shotgun metagenomic sequencing was performed at the University Nebraska Medical Center Genome Sequencing Core facility on an Illumina NextSeq 500 (Illumina, Inc. San Diego, CA). About 2 Gb reads (2 $\times 150$ paired end reads) per sample were generated. Raw reads were trimmed and filtered using Trim Galore! and FASTQC to remove low quality reads and adapter sequences. ${ }^{21}$ Trimmed paired-end reads were analyzed for taxonomic classification using MetaPhlAn 3.0 using the coverage of clade-specific marker genes from the ChocoPhlAn database. ${ }^{22}$ MetaPhlAn 3.0 was conducted with $75 \%$ of nucleotide identity threshold using default parameter settings. The relative abundance of microbial populations was calculated from MetaPhlAn 3.0 results as a local clade abundance (i.e., the number of reads mapping to the clade was estimated by multiplying the local clade abundance by the clade's average genome size) divided by the sum of all local clade abundances. Also, trimmed paired-end reads were analyzed for ARG using ARGs-OAP 2.0 with the comprehensive antibiotic resistance database (CARD), Structured Antibiotic Resistance Genes database (SARG), and the Greengenes database. ${ }^{23}$ ARGs-OAP 2.0 was conducted with an alignment length cutoff of $75 \%$, alignment e-value cutoff of $10^{-7}$, and alignment identity of $80 \%$. ARG abundance generated from ARG-OAP 2.0 were quantified using the following equation (expressed as copy of ARG per copy of $16 \mathrm{~S}$ rRNA gene): ${ }^{24}$

$$
\text { abundance }=\sum_{1}^{n} \frac{N_{\mathrm{ARG} \text { like sequence }} \times L_{\text {reads }} / L_{\mathrm{ARG} \text { reference sequence }}}{N_{16 \mathrm{~S} \text { sequence }} \times L_{\text {reads }} / L_{16 \mathrm{~S} \text { sequence }}}
$$

where $N_{\text {ARG-like sequence }}$ is the number of the ARG-like sequence annotated as one specific ARG reference sequence; $L_{\text {ARG reference sequence }}$ is the sequence length of the corresponding specific ARG reference sequence; $N_{16 \text { s sequence }}$ is the number of the $16 \mathrm{~S}$ sequence identified from the metagenomic data; $L_{16 \mathrm{~S} \text { sequence }}$ is the average length of the $16 \mathrm{~S}$ sequence in the Greengenes database; and $L_{\text {reads }}$ is the sequence length of the Illumina reads. In this work we did not specifically attempt to exclude potential chloroplast sequences in bioinformatic analyses.

Illumina sequencing generated a total of 3756.9 million reads after quality-filtered across 87 samples, with an average of 19.3-23.3 
million reads per sample (Table S2). The numbers of quality-filtered sequences for original soil, manure, surface soil, rhizosphere soil, root, episphere, and endosphere samples were 16.5-20.1, 14.3-23.0, 15.6-35.7, 15.5-35.8, 11.9-28.4, 11.9-40.8, and 12.1-24.8 million reads per DNA sample, respectively (Table $\mathrm{S} 2$ ). The raw sequencing reads were deposited in the NCBI database with the BioProject number PRJNA725852.

\section{Statistical Analysis.}

The taxonomic results from Meta-PhlAn 3.0 and ARG results from ARGs-OAP 2.0 were analyzed for alpha and beta diversity using the vegan package in $\mathrm{R}$ (v. 4.0.5). Principal coordinates analysis (PCoA) using BrayCurtis distance was carried out with the vegan and ggplot2 packages in R. Heatmap was visualized with the pheatmap package in R. Analysis of Variance (ANOVA) and Tukey's honest significance difference (HSD) were performed in $\mathrm{R}$ to determine statistically significant differences. $t$ tests were used to determine if the mean difference between two variables was statistically significant. The effects of manure treatment on microbiome and resistome were tested using the function "ADONIS" of the vegan package in $\mathrm{R}$ with the Bray-Curtis dissimilarity distance matrices as inputs for 1000 permutations.

The SourceTracker function of QIIME was used to quantify the relative contributions of environmental sources to the microbiome and resistome in soil and lettuce. ${ }^{13}$ Five independent runs were conducted to reduce the effect of false predictions. The SourceTracker analysis was carried out using the taxon data at the genus level and ARG family defined in ARGs-OAP. Procrustes analysis was performed to test the correlations between microbiome and resistome using the vegan package in R with 999 permutations. Procrustes Sum of Squares $\mathrm{M}^{2}$ (i.e., sum of squared distances between paired points in the ordination space) and correlation coefficient $r$ in a symmetric Procrustes rotation were reported.

\section{Results}

\section{Microbiome Composition in Soil and Lettuce.}

Actinobacteria, Bacteroidetes, and Proteobacteria dominated the original soil, manure, surface soil, rhizosphere soil, and episphere (Figure S1). Proteobacteria dominated the endosphere and root (Figure S1). The 


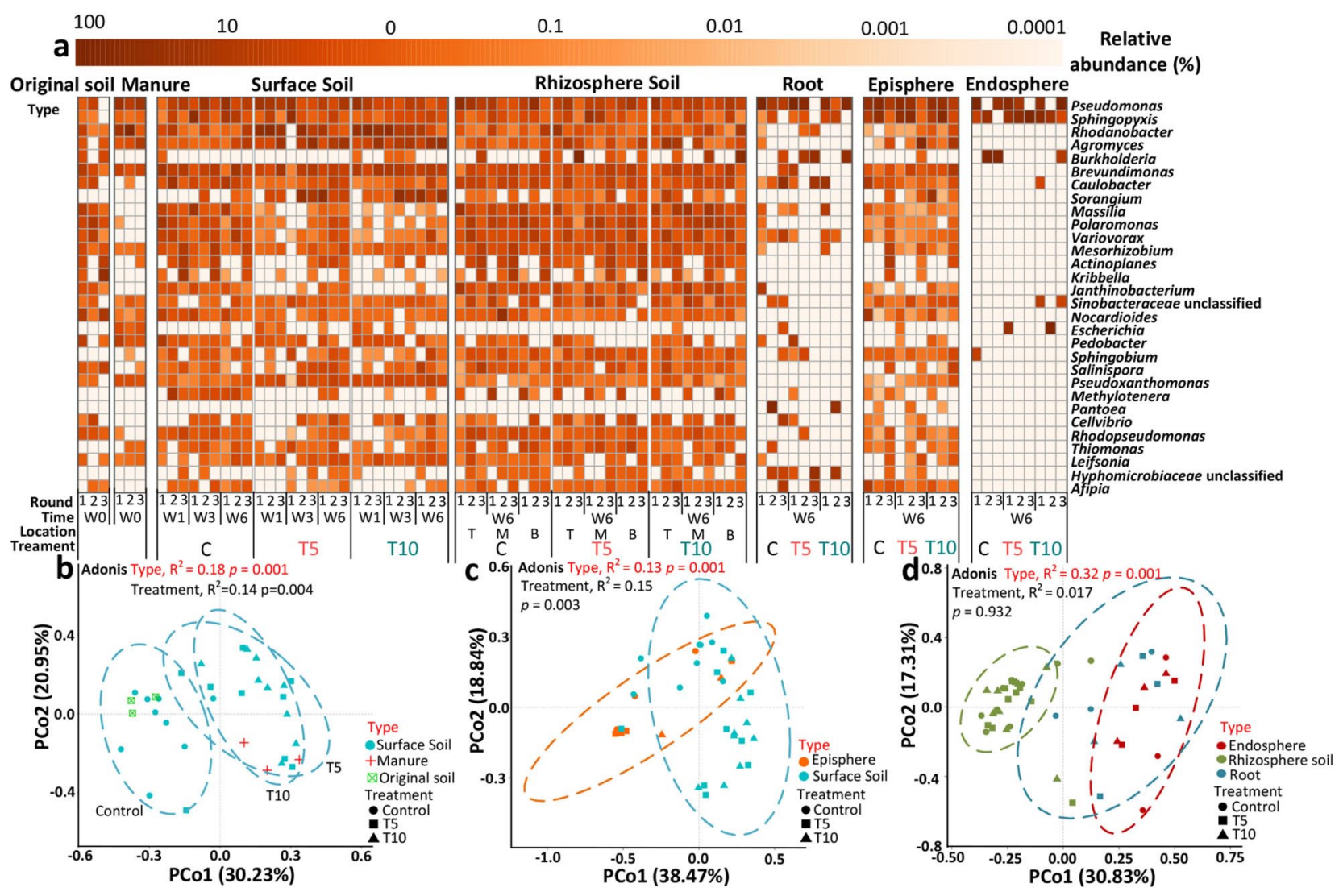

Figure 2. A heatmap showing the top 30 most abundant genera based on average abundance across all sample type and treatment combinations (a). Principal coordinates analysis plots depicting the Bray-Curtis dissimilarity matrices on microbiome composition at the genus level for various sample type and treatment combinations (b-d) with ellipses represent $95 \%$ confidence intervals according to treatment (b) or sample type ( $\mathrm{c}$ and $\mathrm{d}$ ). In the heatmap, T/M/B represent top, medium, and bottom of rhizosphere soil.

top 30 most abundant genera across sample types are reported as a heatmap in Figure 2a. Pseudomonas and Sphingopyxis were the abundant genera across all sample types (Figure 2a). Compared to control, manure application (T5 and T10) significantly increased the abundance of $\mathrm{Ag}$ romyces, Rhodanobacter, and Sorangium in surface soil and episphere $(t$ test, $p$ values $<0.05$ ). The effects of manure treatment on the alpha diversity of the microbiomes in various compartments are described in the SI file and results are shown in Tables S3 and S4. In short, manure treatment had no significant effects on the alpha diversity indexes of sample collected (ANOVA, $p>0.05$ ). 


\section{Beta Diversity of the Microbiome.}

Principal coordinate analysis (PCoA) was conducted to examine the beta diversity among the microbiomes of various sample types under different treatment scenarios using the Bray-Curtis dissimilarity distance calculated at the genus level. First, the effects of manure treatment on the microbiome of surface soil were examined (Figure $2 \mathrm{~b}$ ). The two principal coordinates captured $30.23 \%$ and $20.95 \%$ of the total variations, respectively. Microbiomes in surface soil of control clustered separately from those in surface soil of T5 and T10. Adonis analyses confirmed that manure treatment had significant effects on the microbiomes of surface soil $\left(\mathrm{R}^{2}=0.14, p=0.004\right)$. In addition, the microbiomes in surface soil differed significantly from those in original soil and in manure $\left(\mathrm{R}^{2}=0.18, p=0.001\right)$. The microbiomes of the surface soil from the control overlap with those of original soils, while the microbiomes of the surface soil from treatment (T5 and T10) overlapped with those of manure (Figure $2 \mathrm{~b}$ ).

Second, we examined the microbiomes of surface soil and episphere under different treatment scenarios (Figure 2c). Results show that $38.47 \%$ and $18.84 \%$ of variation could be explained by PCo1 and PCo2, respectively. Adonis analyses show that manure treatment had significant effects on the microbiomes of surface soil and episphere $\left(\mathrm{R}^{2}=0.15\right.$, $p=0.003)$. In addition, there was a significant difference in the microbiome between the surface soil and episphere $\left(\mathrm{R}^{2}=0.13, p=0.001\right)$, although of the microbiomes from these two sample types overlapped.

Third, we examined the microbiomes of endosphere, root, and rhizosphere soil under different treatment scenarios (Figure 2d). Results show that the two principal coordinates captured $30.83 \%$ and $17.31 \%$ of the total variations, respectively. Adonis analysis indicates significant differences in microbiome among sample types $\left(\mathrm{R}^{2}=0.32, p=0.001\right)$, as evidenced by the separation of the rhizosphere microbiomes from the microbiomes in root and endosphere (Figure $2 \mathrm{~d}$ ). In addition, there was no significant impacts of manure treatment on microbiome composition $\left(\mathrm{R}^{2}=0.017, p=0.932\right)$.

\section{Resistome Composition and Abundance in Soil and Lettuce.}

ARGs identified across all sample types conferred resistance to 19 antibiotic families with abundance ranging from $10^{-6}$ to $10^{-1}$ copy ARG per copy of $16 \mathrm{~S}$ rRNA gene (Figure 3a). Bacitracin, fosmidomycin, 


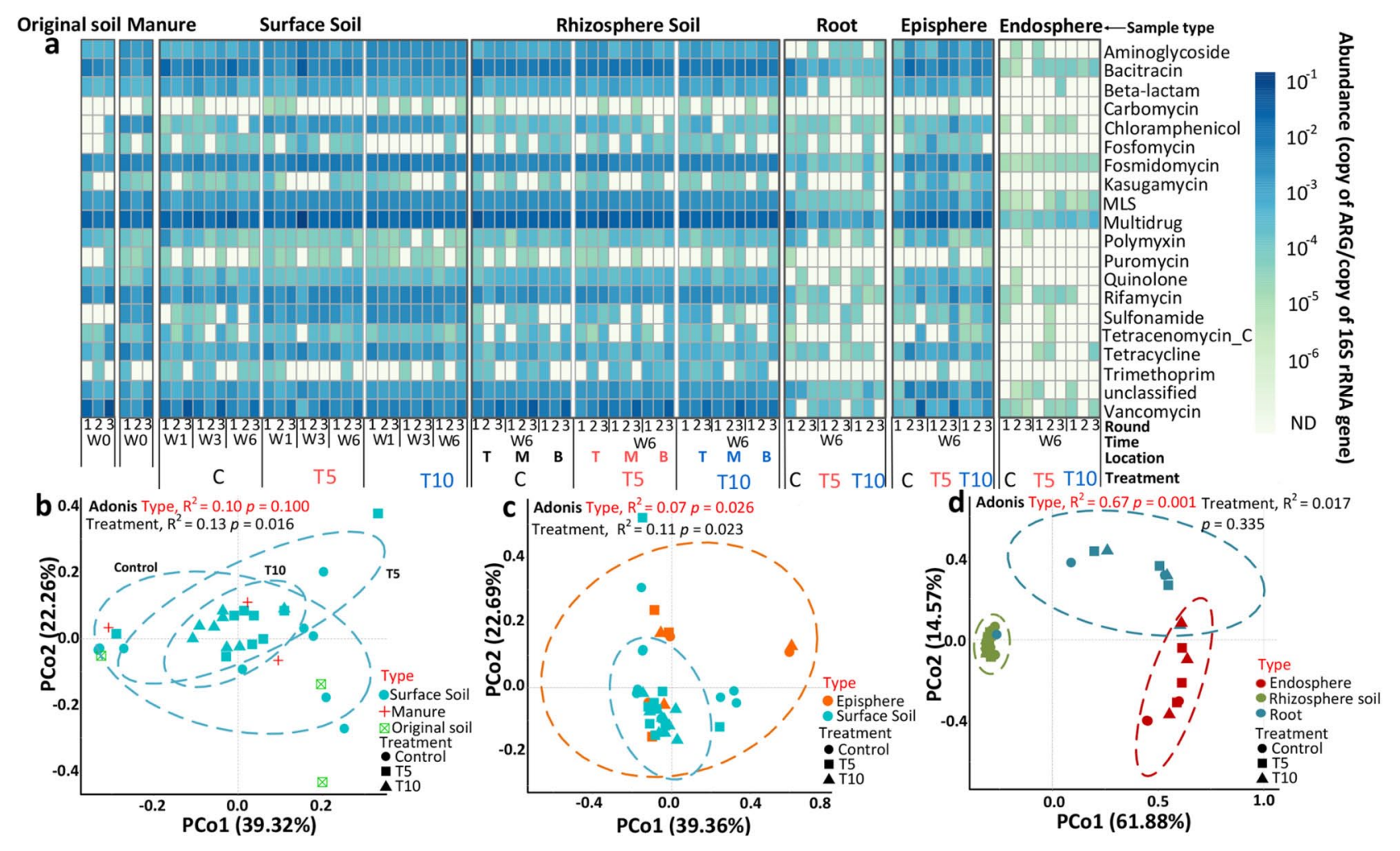

Figure 3. A heatmap showing the abundance of ARG families across different sample types and treatment scenarios (a). PCoA plots depicting the Bray-Curtis dissimilarity matrices on resistome composition at the ARG family level for various sample type and treatment combinations (b-d) with ellipses represent 95\% confidence intervals according to treatment (b) or sample type (c and d). In the heatmap, T/M/B represent top, medium, and bottom of rhizosphere soil.

macrolide-lincosamidestreptogramin (MLS), multidrug, and vancomycin resistance genes were the most abundant ARG families across all sample types. All ARG families were present in manure, while ARG families such as chloramphenicol, fosfomycin, sulfonamide, and Trimethoprim were only sporadically present in the original soil.

For all types of samples tested, the total abundance of ARGs ranged from $3 \times 10^{-4}-8 \times 10^{-1}$ copy of ARG per copy of $16 \mathrm{~S}$ rRNA gene. The total ARG abundance in the five sample types (i.e., surface soil, rhizosphere soil, root, episphere, and endosphere) was not affected significantly by manure treatment (ANOVA, $p=0.211-0.851$ in the last row of Table S5). The total abundance of ARGs in surface soil $\left(1.7 \times 10^{-1}-4.0 \times 10^{-1}\right.$ ARG per 16S rRNA gene), rhizosphere soil $\left(1.9 \times 10^{-1}-2.4 \times 10^{-1}\right)$, and 
episphere $\left(1.3 \times 10^{-1}-2.1 \times 10^{-1}\right)$ was significantly higher (ANOVA and Tukey's HSD, $p$ values $<0.05)$ than that in $\operatorname{root}\left(9.0 \times 10^{-3}\right.$ to $\left.1.9 \times 10^{-2}\right)$ and endosphere $\left(5.0 \times 10^{-4}\right.$ to $\left.1.7 \times 10^{-3}\right)$.

ANOVA analysis shows that manure treatment had significant effects on the abundance of select ARG families in surface soil (Table S5, i.e., aminoglycoside, chloramphenicol, fosmidomycin, MLS, rifamycin, sulfonamide, and tetracycline). Tukey's HSD analysis shows that manure application significantly increased the abundances of these seven ARG families in surface soil receiving manure (Figure S2, $p$ values $<0.05$ ). Besides, the abundances of these seven ARG families in surface soil of T5 and T10 generally decreased over time (Figure S2). A significant interaction between manure treatment and sampling time existed for tetracycline resistance genes, showing significantly lower abundance in Week 6 than in Week 1 for T5 and T10 (Figure S2, Turkey's HSD $p$ values <0.05).

Manure treatment had a significant impact only on the abundance of sulfonamide resistance genes in rhizosphere soil (Table S5, $p=0.026$ ). In comparison, the sampling location had a significant effect on the abundance of aminoglycoside, chloramphenicol, fosmidomycin, rifamycin, and sulfonamide resistance genes in rhizosphere soil (Table S5, ANOVA, $p=0.008-0.020$ ). ARGs belonging to these antibiotic families, except for sulfonamide resistance genes, exhibited significantly higher abundance (ANOVA and Turkey's HSD, $p$ values $<0.05$ ) in top rhizosphere soil than in middle and bottom rhizosphere soil, respectively (Figure S3).

Manure treatment had no significant impact on the abundance of any of the resistance gene families in root or episphere (Table S5). In comparison, manure treatment exhibited significant impacts on abundances of bacitracin, fosmidomycin and rifamycin resistance genes in endosphere (Table S5). Manure application caused significantly higher (Turkey's HSD, $p$ values $<0.05$ ) abundance of bacitracin resistance genes in $\mathrm{T} 5$ and $\mathrm{T} 10$ than in $\mathrm{C}$, of fosmidomycin resistance genes in $\mathrm{T} 10$ than in $\mathrm{T} 5$ and $\mathrm{C}$, and of rifamycin resistance genes in T5 than in T10 and C (Figure S4). Sample type had significant impacts (ANOVA, $p$ values $<0.05$ ) on the abundance of nearly all the ARG families tested, except for carbomycin, fosfomycin, and polymyxin resistance genes (Table S5, ANOVA, $p$ values $>0.05$ ). Finally, the effects of manure treatment on the alpha diversity of the resistome in various compartments 
is described in the SI file, and the results are summarized in Tables S6 and S7. In short, both manure treatment and sample type had significant effects on the alpha diversity indexes for the resistomes characterized (Table S7, ANOVA, $p<0.05$ ), with significantly higher values for T5 and/or T10 than for Control in surface soil and in episphere (Table S6, Tukey's test, $p<0.05$ ).

\section{Beta Diversity of Resistome.}

PCoA plots were established to examine the beta diversity of resistomes in various sample types under different treatment scenarios based on the Bray-Curtis dissimilarity distance calculated at the ARG family level. First, the effects of manure treatment on the resistome of surface soil were examined (Figure $3 \mathrm{~b}$ ). The two principal coordinates captured $39.32 \%$ and $22.26 \%$ of the total variations among ARG compositions. Although the resistome in the surface soil of control overlaps with that in the surface soil of T5 and T10, Adonis analysis shows a significant effect of manure treatment on the ARG composition among three treatment scenarios (Figure $3 \mathrm{~b}, \mathrm{R}^{2}=0.13, p=0.016$ ). According to Adonis analyses, sample type had no significant effects on the resistome $\left(\mathrm{R}^{2}=0.10, p=0.100\right)$.

Second, we examined the resistomes of surface soil and episphere under different treatment scenarios. A PCoA plot was established for surface soil and episphere under the three treatment scenarios (Figure 3c). Adonis analysis shows that manure treatment had significant impacts on the resistome compositions for both sample types (Figure $3 c, \mathrm{R}^{2}=0.11, p=0.023$ ). There was an overlap between the resistomes of surface soil and the episphere, however, Adonis analyses shows that sample type had significant impacts on resistome composition (Figure $3 c, \mathrm{R}^{2}=0.07, p=0.026$ ).

Third, we examined the resistome of endosphere, root, and rhizosphere soil under different treatment scenarios. A PCoA plot was established for the resistomes in three sample types under different treatment scenarios (Figure 3d). Results show significant difference in the resistome composition among the sample types (Adonis, $\mathrm{R}^{2}=0.67, p=$ 0.001 ), consistent with the separate clustering of three sample types in Figure 3d. Manure treatment had no significant impact on the resistome composition in the three sample types (Figure $3 \mathrm{~d}$, Adonis $\mathrm{R}^{2}=0.017, p$ $=0.335$ ). 

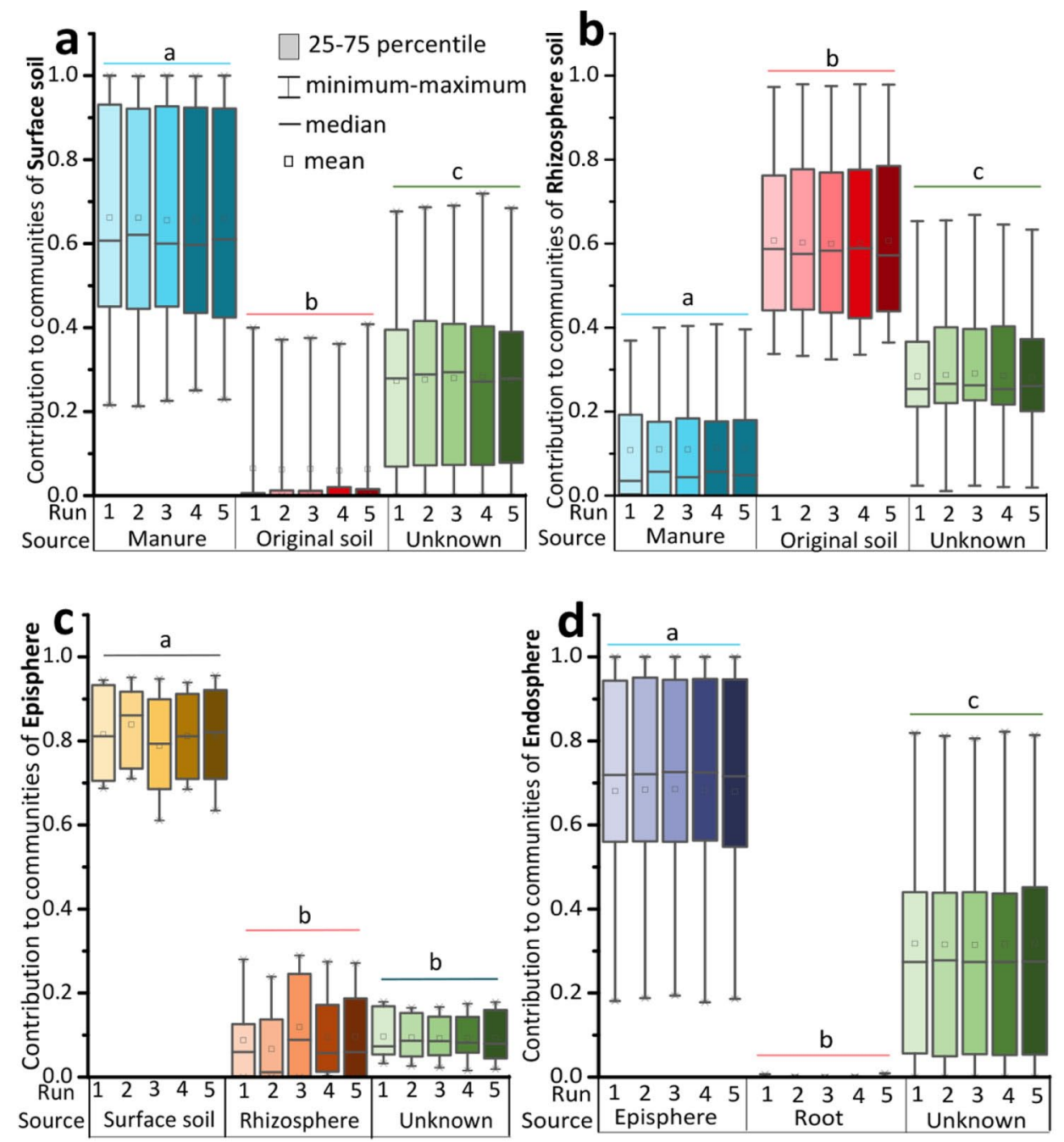

Figure 4. Box plots showing the results of SourceTracker analysis (five runs) on the relative contribution of various sources to the microbiome of surface soil (a, $n=16)$, rhizosphere soil (b, $n=16$ ), episphere (c, $n=6)$, and endosphere (d, $n=6$ ) following manure treatment (i.e., T5 and T10). Box group with different letter represents statistically significant group (one-way ANOVA, $p<0.05$ ).

\section{Attribution of Sources to the Lettuce Associated Microbiome and Resistome.}

Conceptual models were established to test the three hypotheses by assigning the source and sinks of the microbiome and resistome in the soil-plant ecosystem. To test Hypothesis 1, surface soil (Figures 4a and $5 \mathrm{a}$ ) and rhizosphere soil (Figures $4 \mathrm{~b}$ and $5 \mathrm{~b}$ ) were each defined as an environmental sink, while manure and original soil were defined as 

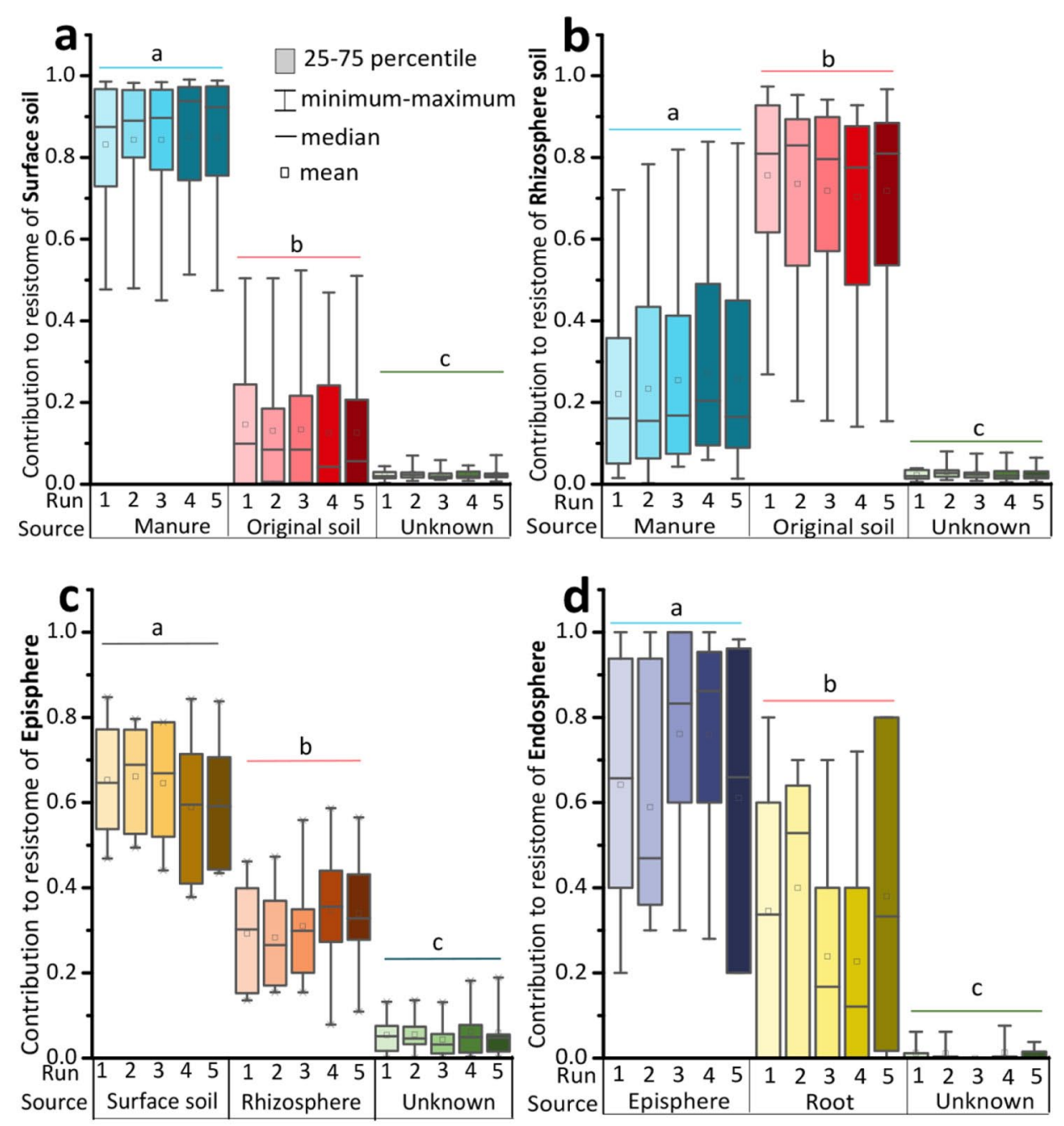

Figure 5. Box plots showing the results of SourceTracker analysis (five runs) on the relative contribution of various sources to the resistomes of surface soil (a, $n=18)$, rhizosphere soil (b, $n=18$ ), episphere (c, $n=6)$ ), and endosphere (d, $n=6$ ) following manure treatment (i.e., T5 and T10). Box group with different letter represents significant group (one-way ANOVA, $p<0.05$ ).

environmental sources. To test Hypothesis 2, episphere was defined as an environmental sink, while surface soil and rhizosphere soil as environmental sources (Figures $4 \mathrm{c}$ and $5 \mathrm{c}$ ). To test Hypothesis 3, endosphere was defined as an environment sink, while episphere and root were defined as environmental sources (Figures $4 \mathrm{~d}$ and $5 \mathrm{~d}$ ).

Manure was a significant source of the microbiome (average 65.6\% to $66.2 \%$ ) in surface soil over the 6-week growth period (Figure 4a). 
The contribution of the original soil to the surface soil was minimum, while unknown sources attributed $27.2 \%$ to $28.3 \%$ to the microbiome in surface soil. In comparison, original soil was the main contributor to the microbiome in rhizosphere soil (average 60.0\% to 61.0\%) (Figure 4b). Manure contributed on average $10.8 \%$ to $11.4 \%$ of the microbiome in the rhizosphere soil, while unknown sources contributed again for $28.1 \%$ to $29.1 \%$.

Surface soil was a significant source of the microbiome $(78.8 \%$ to 83.9\%) in episphere (Figure 4c). The unknown sources attributed 10.2\% to $10.7 \%$ to the microbiome in surface soil. Episphere was a significant contributor to the microbiome (58.9\% to $59.7 \%$ ) in the endosphere. The root contributed on average $14.0 \%$ to $14.6 \%$, while unknown sources contributed for $26.2 \%$ to $26.6 \%$ (Figure $4 \mathrm{~d}$ ).

The SourceTracker analyses focusing on the resistome yielded strikingly similar results to those for microbiome. Manure was estimated to be the biggest contributor of resistome (83.2\% to $85.2 \%$ ) in surface soil (Figure $5 \mathrm{a}$ ), compared to original soil (12.5\% to $14.6 \%$ ) and unknown sources $(2.2 \%$ to $2.6 \%)$. Original soil was the biggest contributor of resistome (70.4\% to $75.6 \%$ ) in rhizosphere soil (Figure $5 \mathrm{~b}$ ). Additionally, compared to rhizosphere soil (28.3\% to $34.8 \%)$ and unknown sources (4.3\% to $6.2 \%$ ), surface soil was the most significant source of resistome (58.9\% to $66.1 \%$ ) in episphere (Figure $5 \mathrm{c}$ ). For resistome in endosphere, episphere (58.9\% to $76.1 \%$ ) was a more significant source than root (22.7\% to $40.0 \%$, Figure $5 d)$.

\section{Discussion}

\section{Overall Results from Hypothesis Testing.}

Manure application clearly affects the microbiome and resistome of both soil and lettuce (Figures 2-5). Our results support Hypothesis 1 , that is, manure application mostly affected the microbiome and resistome of surface soil, not rhizosphere soil. We also proved Hypothesis 2 : the microbiome and resistome associated with lettuce episphere were mainly contributed from surface soil. However, contrary to our original idea, our findings disproved Hypothesis 3. According to our results, the microbiome and resistome associated with lettuce endosphere were mainly attributed from those on episphere, not those in root. 


\section{Microbiome and Resistomes in Surface and Rhizosphere Soil.}

Manure application significantly altered the composition (Figure 3c) and increased the diversity (Tables S4 and S6) of the microbiome and resistome in surface soil. In particular, manure application introduced sulfonamide and tetracycline resistance genes to surface soil (Figure S5). Increases in sulfonamide resistance genes (sul1 and sul2) was also reported for soils receiving swine ${ }^{25}$ and dairy manure ${ }^{26}$ due to the introduction of manure-borne ARGs. Studies have reported that manure-borne ARGs could persist in surface soil for more than a year. ${ }^{26,27}$ The persistence of manure-borne microbes in soil leads to their potential transmission to crop plants.

Surface applied manure had limited impacts on the microbiome and resistome of rhizosphere soil. The vertical transport of manure borne microbes in soil is affected by soil characteristics such as moisture content, nutrient level, bulk density, and soil pore size. ${ }^{28}$ The soil used in the present study is sandy loam containing $22.5 \%$ silt, $15.0 \%$ clay, and $62.5 \%$ sand. The maximum concentration of manure-borne microbes was found at $5 \mathrm{~cm}$ depth of sandy soil and manure-borne microbes significantly decreased at $10 \mathrm{~cm}$ soil depth due to adsorption to soil particles. ${ }^{29}$ Our previous work showed that most of the ARGs tested were not quantifiable using qPCR beneath the top $10 \mathrm{~cm}$ layer of silty clay loam following swine manure application. ${ }^{30}$ In addition, most of the microbes that travel vertically are expected to transport through the bulk soil, not the rhizosphere soil. ${ }^{31}$

\section{Microbiome and Resistome in Episphere.}

Similarities in the microbiome between the surface soil and episphere have been reported. The episphere microbiome of Brassica grown in soil amended with struvite ${ }^{8}$ and the episphere of grapevine ${ }^{12}$ show overlaps with the soil microbiome. The manure microbiome can impact the surface soil microbiome and persist for an extended period of time, ${ }^{32-34}$ making them a potential source of the microbiome on the episphere. ${ }^{35}$

The transmission of microbes from surface soil to episphere may be accomplished through splashing and direct contact. During overhead irrigation and rainfall events, microbes in surface soil may get splashed onto the plant episphere. ${ }^{6}$ William et al. ${ }^{36}$ reported that overhead irrigation resulted in more bacterial cells in the episphere of Romaine lettuce than did drip-irrigation. In addition, direct contact between vegetables 
and surface soil can occur during the entire growth period. For example, Escherichia coli 0157:H7 can adhere to the surface of germinating lettuce seeds, ${ }^{37}$ and appear on cotyledons and hypocotyls of lettuce seedlings grown in manured soil when the seedlings grow and break through the soil surface. ${ }^{38}$

\section{Microbiome and Resistome in Endosphere.}

There are several pathways through which bacteria can enter plants and become endophytes. Bacteria from the episphere can enter the endosphere via stomata, ${ }^{39}$ scar tissue, ${ }^{40}$ and surface wounds ${ }^{41}$ on the leaf of various kinds of vegetable. Alternatively, bacteria can also become endophytes after entering the root from the rhizosphere soil through breaks in the epidermis and translocate to the edible parts of the plant. ${ }^{38}$

In this study, we specifically compared the relative contributions of the episphere and root to the microbiome and resistome in the endosphere using SourceTracker analysis. We found that endospheric resistomes are transmitted chiefly from the episphere and partially from the root (Figure $5 \mathrm{~d}$ ). This reinforces the notion that the resistome in lettuce leaves might transmit from both the exterior (through the episphere) and interior (through the root) of lettuce tissue..$^{3,4,10,11,42,43}$ In our study, manure had a more significant impact on the microbiome and resistome in surface soil than rhizosphere soil. Therefore, we propose that the transmission route of manure- surface soil-episphere is more important than the transmission route of manure-rhizosphere soil-root in shaping the microbiome and resistome in endosphere.

\section{Plant-Associated Microbiomes.}

The microbiome in the soil, manure, surface soil, rhizosphere soil, and episphere were dominated by Actinobacteria, Bacteroidete, and Proteobacteria, which have been reported as the dominant members in the microbiomes of lettuce grown in soil irrigated with wastewater, ${ }^{20}$ and in soil receiving manure ${ }^{11}$ or biosolids. ${ }^{42}$ Pseudomonas and Sphingopyxis were the dominant Proteobacteria genera across all the sample types, especially in the root, episphere, and endosphere. These two genera appeared in the soil, leaves, flowers, and grapes of planted grapevine, ${ }^{12}$ suggesting their ability to survive a broad range of environments. Indeed, Pseudomonas has been recovered from the root, ${ }^{44}$ episphere, ${ }^{45,46}$ and endosphere ${ }^{47}$ of lettuce. Some species within Pseudomonas were known for their beneficial effects to plants by solubilizing inorganic phosphate ${ }^{48}$ 
and enhancing nutrient uptake. ${ }^{49}$ Pathogenic Pseudomonas species carrying ARGs such as sul1 and sul2 were also reported in manured soils, 50,51 and are presumably able to transmit ARGs from the soil/manure to lettuce. Sphingopyxis was commonly found in the soils around poultry and livestock operations ${ }^{51}$ and in lettuce root. ${ }^{52}$ Some Sphingopyxis isolates recovered from soil contained sulfonamide resistance genes. ${ }^{51}$

\section{Microbiome vs Resistome.}

The microbiome and the resistome of the soil-plant ecosystem are likely correlated. ${ }^{53}$ Procrustes test results show significant correlations between the resistome and microbiome in the episphere and surface soil (Figure S7a, $M^{2}=0.36, r=0.80, p=0.001$ ) and in the endosphere, rhizosphere soil, and root (Figure S7b, $M^{2}=0.40, r=0.77, p=0.001$ ). This finding is consistent with previous studies reporting significant correlations between ARGs and the microbiome in the rhizosphere soil of Brassica $^{8}$ and soil with manure application ${ }^{54}$ using Procrustes analysis.

\section{Environmental Significance.}

We tested three hypotheses on the transmission of manure-borne microbiome and resistome in the soil-plant ecosystem. Compared to the rhizosphere soil, the surface soil in croplands receiving manure via broadcasting appears to be a more important source of crop-associated microbiome and resistome. This highlights the importance of prior aging to control the transmission of the manure-borne resistome to crops. Furthermore, reduction of transmission from the surface soil to leaf surface is recommended, as the leaf episphere is also an important source of the microbiome and resistome of leaf endosphere. Hence, irrigation practices such as subsurface drip and trickle irrigation are recommended to reduce the overall transmission of manure-borne microbes and ARGs to crops.

Supporting Information Supporting Information (PDF) follows the References, including:

- alpha diversity of microbiome and resistome

- sampling scheme; ANOVA analyses for ARG abundance

- relative abundance of phyla

- abundance of ARG families and the top 100 ARGs

- numbers of ARGs shared

- Procrustes test between resistomes and microbiomes 
Acknowledgments This study was supported by the National Science Foundation (CBET-1351676 and CBET-1805990) and US Department of Agriculture (2017-6800326497). This work was completed utilizing the Holland Computing Center of the University of Nebraska, which receives support from the Nebraska Research Initiative. Shotgun metagenomics was performed by the UNMC DNA Sequencing Core Facility, which receives partial support from the National Institute for General Medical Science (NIGMS) INBRE-P20GM103427-19 grant as well as the Fred \& Pamela Buffett Cancer Center Support Grant-P30 CA036727. This publication's contents are the sole responsibility of the authors and do not necessarily represent the official views of the NIH or NIGMS.

The authors declare no competing financial interest.

\section{References}

(1) Luo, G.; Li, L.; Friman, V.-P.; Guo, J.; Guo, S.; Shen, Q.; Ling, N. Organic amendments increase crop yields by improving microbe-mediated soil functioning of agroecosystems: A meta-analysis. Soil Biol. Biochem. 2018, 124, 105-115.

(2) Alegbeleye, O. O.; Singleton, I.; Sant'Ana, A. S. Sources and contamination routes of microbial pathogens to fresh produce during field cultivation: a review. Food Microbiol. 2018, 73, 177-208.

(3) Zhu, B.; Chen, Q.; Chen, S.; Zhu, Y.-G. Does organically produced lettuce harbor higher abundance of antibiotic resistance genes than conventionally produced? Environ. Int. 2017, 98, 152-159.

(4) Wang, F.-H.; Qiao, M.; Chen, Z.; Su, J.-Q.; Zhu, Y.-G. Antibiotic resistance genes in manure-amended soil and vegetables at harvest. J. Hazard. Mater. 2015, 299, 215-221.

(5) Fogler, K.; Guron, G. K.; Wind, L. L.; Keenum, I. M.; Hession, W. C.; Krometis, L.-A.; Strawn, L. K.; Pruden, A.; Ponder, M. A. Microbiota and antibiotic resistome of lettuce leaves and radishes grown in soils receiving manure-based amendments derived from antibiotic-treated cows. Front. Sustain. Food Syst. 2019, 3, 22.

(6) Marti, R.; Scott, A.; Tien, Y.-C.; Murray, R.; Sabourin, L.; Zhang, Y.; Topp, E. Impact of manure fertilization on the abundance of antibiotic-resistant bacteria and frequency of detection of antibiotic resistance genes in soil and on vegetables at harvest. Appl. Environ. Microbiol. 2013, 79 (18), 5701-5709.

(7) US Food and Drug Administration (US FDA). Standards for the Growing, Harvesting, Packing, and Holding of Produce for Human Consumption. Food Safety Modernization Act (FSMA).US FDA: Washington, DC: 2015.

(8) Chen, Q.-L.; An, X.-L.; Zhu, Y.-G.; Su, J.-Q.; Gillings, M. R.; Ye, Z.-L.; Cui, L. Application of struvite alters the antibiotic resistome in soil, rhizosphere, and phyllosphere. Environ. Sci. Technol. 2017, 51(14), 8149-8157.

(9) Ruiz-Pérez, C. A.; Restrepo, S.; Zambrano, M. M. Microbial and functional diversity within the phyllosphere of Espeletia species in an Andean high-mountain ecosystem. Appl. Environ. Microbiol. 2016, 82(6), 1807-1817. 
(10) Wang, C.; Hu, R.; Strong, P.; Zhuang, W.; Huang, W.; Luo, Z.; Yan, Q.; He, Z.; Shu, L. Prevalence of antibiotic resistance genes and bacterial pathogens along the soilmangrove root continuum. J. Hazard. Mater. 2021, 408, 124985.

(11) Zhang, Y.-J.; Hu, H.-W.; Chen, Q.-L.; Singh, B. K.; Yan, H.; Chen, D.; He, J.-Z. Transfer of antibiotic resistance from manure-amended soils to vegetable microbiomes. Environ. Int. 2019, 130, 104912.

(12) Zarraonaindia, I.; Owens, S. M.; Weisenhorn, P.; West, K.; Hampton-Marcell, J.; Lax, S.; Bokulich, N. A.; Mills, D. A.; Martin, G.; Taghavi, S.; van der Lelie, D.; Gilbert, J. A. The soil microbiome influences grapevine-associated microbiota. mBio 2015, 6 (2), No. e02527-14.

(13) Knights, D.; Kuczynski, J.; Charlson, E. S.; Zaneveld, J.; Mozer, M. C.; Collman, R. G.; Bushman, F. D.; Knight, R.; Kelley, S. T. Bayesian community-wide cultureindependent microbial source tracking. Nat. Methods 2011, 8 (9), 761-763.

(14) Griffiths, T. L.; Steyvers, M. Finding scientific topics. Proc. Natl. Acad. Sci. U. S. A. 2004, 101 (S1), 5228-5235.

(15) Neumann, G.; George, T. S.; Plassard, C. Strategies and methods for studying the rhizosphere-the plant science toolbox. Plant Soil 2009, 321 (1), 431-456.

(16) Fahrenfeld, N.; Knowlton, K.; Krometis, L. A.; Hession, W. C.; Xia, K.; Lipscomb, E.; Libuit, K.; Green, B. L.; Pruden, A. Effect of manure application on abundance of antibiotic resistance genes and their attenuation rates in soil: field-scale mass balance approach. Environ. Sci. Technol. 2014, 48 (5), 2643-2650.

(17) Tang, X.; Lou, C.; Wang, S.; Lu, Y.; Liu, M.; Hashmi, M. Z.; Liang, X.; Li, Z.; Liao, Y.; Qin, W.; Fan, F.; Xu, J.; Brookes, P. C. Effects of long-term manure applications on the occurrence of antibiotics and antibiotic resistance genes (ARGs) in paddy soils: evidence from four field experiments in south of China. Soil Biol. Biochem. 2015, 90, 179-187.

(18) Chen, C.; Guron, G. K.; Pruden, A.; Ponder, M.; Du, P.; Xia, K. Antibiotics and antibiotic resistance genes in bulk and rhizosphere soils subject to manure amendment and vegetable cultivation. J. Environ. Qual. 2018, 47 (6), 1318-1326.

(19) Lundberg, D. S.; Lebeis, S. L.; Paredes, S. H.; Yourstone, S.; Gehring, J.; Malfatti, S.; Tremblay, J.; Engelbrektson, A.; Kunin, V.; Rio, T. G. d.; Edgar, R. C.; Eickhorst, T.; Ley, R. E.; Hugenholtz, P.; Tringe, S. G.; Dangl, J. L. Defining the core Arabidopsis thaliana root microbiome. Nature 2012, 488 (7409), 86-90.

(20) Zhang, Y.; Jewett, C.; Gilley, J.; Bartelt-Hunt, S. L.; Snow, D. D.; Hodges, L.; Li, X. Microbial communities in the rhizosphere and the root of lettuce as affected by Salmonella-contaminated irrigation water. FEMS Microbiol. Ecol. 2018, 94 (9), No. fiy135.

(21) Krueger, F., Trim Galore: a wrapper tool around Cutadapt and FastQC to consistently apply quality and adapter trimming to FastQ files, with some extra functionality for MspI-digested RRBS-type (Reduced Representation BisufiteSeq) libraries. URL http://www.bioinformatics.babraham.ac.uk/projects/trim galore/ (Accessed 4/28/2016), 2012. 
(22) Beghini, F.; McIver, L. J; Blanco-Miguez, A.; Dubois, L.; Asnicar, F.; Maharjan, S.; Mailyan, A.; Manghi, P.; Scholz, M.; Thomas, A. M.; Valles-Colomer, M.; Weingart, G.; Zhang, Y.; Zolfo, M.; Huttenhower, C.; Franzosa, E. A; Segata, N. Integrating taxonomic, functional, and strain-level profiling of diverse microbial communities with bioBakery 3. eLife 2021, 10. DOI: 10.7554/ eLife.65088.

(23) Yin, X.; Jiang, X.-T.; Chai, B.; Li, L.; Yang, Y.; Cole, J. R.; Tiedje, J. M.; Zhang, T. ARGsOAP v2.0 with an expanded SARG database and Hidden Markov Models for enhancement characterization and quantification of antibiotic resistance genes in environmental metagenomes. Bioinformatics 2018, 34 (13), 2263-2270.

(24) Li, B.; Yang, Y.; Ma, L.; Ju, F.; Guo, F.; Tiedje, J. M.; Zhang, T. Metagenomic and network analysis reveal wide distribution and co-occurrence of environmental antibiotic resistance genes. ISME J. 2015, 9 (11), 2490-2502.

(25) Jechalke, S.; Kopmann, C.; Rosendahl, I.; Groeneweg, J.; Weichelt, V.; Krogerrecklenfort, E.; Brandes, N.; Nordwig, M.; Ding, G.-C.; Siemens, J.; Heuer, H.; Smalla, K. Increased abundance and transferability of resistance genes after field application of manure from sulfadiazine-treated pigs. Appl. Environ. Microbiol. 2013, 79 (5), 1704-1711.

(26) Marti, R.; Tien, Y.-C.; Murray, R.; Scott, A.; Sabourin, L.; Topp, E. Safely coupling livestock and crop production systems: how rapidly do antibiotic resistance genes dissipate in soil following a commercial application of swine or dairy manure? Appl. Environ. Microbiol. 2014, 80 (10), 3258-3265.

(27) Liu, W.; Ling, N.; Guo, J.; Ruan, Y.; Wang, M.; Shen, Q.; Guo, S. Dynamics of the antibiotic resistome in agricultural soils amended with different sources of animal manures over three consecutive years. J. Hazard. Mater. 2021, 401, 123399.

(28) Yang, P.; van Elsas, J. D. Mechanisms and ecological implications of the movement of bacteria in soil. Appl. Soil Ecol. 2018, 129, 112-120.

(29) Sepehrnia, N.; Memarianfard, L.; Moosavi, A.; Bachmann, J.; Rezanezhad, F.; Sepehri, M. Retention modes of manure-fecal coliforms in soil under saturated hydraulic condition. J. Environ. Manage. 2018, 227, 209-215.

(30) Hall, M. C.; Mware, N. A.; Gilley, J. E.; Bartelt-Hunt, S. L.; Snow, D. D.; Schmidt, A. M.; Eskridge, K. M.; Li, X. Influence of setback distance on antibiotics and antibiotic resistance genes in runoff and soil following the land application of swine manure slurry. Environ. Sci. Technol. 2020, 54 (8), 4800-4809.

(31) Ai, C.; Liang, G.; Sun, J.; Wang, X.; Zhou, W. Responses of extracellular enzyme activities and microbial community in both the rhizosphere and bulk soil to long-term fertilization practices in a fluvoaquic soil. Geoderma 2012, 173, 330-338.

(32) Wang, H.; Sangwan, N.; Li, H.-Y.; Su, J.-Q.; Oyang, W.-Y.; Zhang, Z.-J.; Gilbert, J. A.; Zhu, Y.-G.; Ping, F.; Zhang, H.-L. The antibiotic resistome of swine manure is significantly altered by association with the Musca domestica larvae gut microbiome. ISME J. 2017, 11 (1), 100-111.

(33) Zhang, Y.-J.; Hu, H.-W.; Chen, Q.-L.; Yan, H.; Wang, J.-T.; Chen, D.; He, J.-Z. Manure application did not enrich antibiotic resistance genes in root endophytic 
bacterial microbiota of cherry radish plants. Appl. Environ. Microbiol. 2020, 86

(2), No. e02106-19.

(34) Chen, Q.-L.; An, X.-L.; Li, H.; Zhu, Y.-G.; Su, J.-Q.; Cui, L. Do manure-borne or indigenous soil microorganisms influence the spread of antibiotic resistance genes in manured soil? Soil Biol. Biochem. 2017, 114, 229-237.

(35) Benner, J. W.; Vitousek, P. M. Development of a diverse epiphyte community in response to phosphorus fertilization. Ecology Lett. 2007, 10 (7), 628-636.

(36) Williams, T. R.; Moyne, A.-L.; Harris, L. J.; Marco, M. L. Season, irrigation, leaf age, and Escherichia coli inoculation influence the bacterial diversity in the lettuce phyllosphere. PLoS One 2013, 8(7), No. e68642.

(37) Wachtel, M. R.; Whitehand, L. C.; Mandrell, R. E. Association of Escherichia coli 0157: H7 with preharvest leaf lettuce upon exposure to contaminated irrigation water. J. Food Prot. 2002, 65 (1), 18-25.

(38) Solomon, E. B.; Yaron, S.; Matthews, K. R. Transmission of Escherichia coli 0157: $\mathrm{H} 7$ from contaminated manure and irrigation water to lettuce plant tissue and its subsequent internalization. Appl. Environ. Microbiol. 2002, 68 (1), 397-400.

(39) Frank, A. C.; Saldierna Guzmán, J. P.; Shay, J. E. Transmission of bacterial endophytes. Microorganisms 2017, 5 (4), 70.

(40) Guo, X.; Chen, J.; Brackett, R. E.; Beuchat, L. R. Survival of Salmonellae on and in tomato plants from the time of inoculation at flowering and early stages of fruit development through fruit ripening. Appl. Environ. Microbiol. 2001, 67 (10), 4760-4764.

(41) Compant, S.; Mitter, B.; Colli-Mull, J. G.; Gangl, H.; Sessitsch, A. Endophytes of grapevine flowers, berries, and seeds: identification of cultivable bacteria, comparison with other plant parts, and visualization of niches of colonization. Microb. Ecol. 2011, 62 (1), 188-197.

(42) Yang, L.; Liu, W.; Zhu, D.; Hou, J.; Ma, T.; Wu, L.; Zhu, Y.; Christie, P. Application of biosolids drives the diversity of antibiotic resistance genes in soil and lettuce at harvest. Soil Biol. Biochem. 2018, 122, 131-140.

(43) Xiang, Q.; Zhu, D.; Giles, M.; Neilson, R.; Yang, X.-R.; Qiao, M.; Chen, Q.L. Agricultural activities affect the pattern of the resistome within the phyllosphere microbiome in peri-urban environments. J. Hazard. Mater. 2020, 382, 121068.

(44) Shen, Y.; Stedtfeld, R. D.; Guo, X.; Bhalsod, G. D.; Jeon, S.; Tiedje, J. M.; Li, H.; Zhang, W. Pharmaceutical exposure changed antibiotic resistance genes and bacterial communities in soil-surface- and overhead-irrigated greenhouse lettuce. Environ. Int. 2019, 131, 105031.

(45) Luziatelli, F.; Ficca, A. G.; Colla, G.; Baldassarre Švecová, E.; Ruzzi, M. Foliar application of vegetal-derived bioactive compounds stimulates the growth of beneficial bacteria and enhances microbiome biodiversity in lettuce. Front. Plant Sci. 2019, 10, 60.

(46) Medina-Salazar, S. A.; Rodríguez-Aguilar, M.; Vallejo-Pérez, M. R.; FloresRamírez, R.; Marin-Sanchez, J.; Aguilar-Benitez, G.; Jarquin-Galvez, R.; LaraÁvila, J. P. Biodiversity of epiphytic Pseudomonas strains isolated from leaves of pepper and lettuce. Biologia 2020, 75, 773-784. 
(47) Gao, F.-Z.; He, L.-Y.; He, L.-X.; Zou, H.-Y.; Zhang, M.; Wu, D.- L.; Liu, Y.-S.; Shi, Y.J.; Bai, H.; Ying, G.-G. Untreated swine wastes changed antibiotic resistance and microbial community in the soils and impacted abundances of antibiotic resistance genes in the vegetables. Sci. Total Environ. 2020, 741, 140482.

(48) Kwak, Y.; Jung, B. K.; Shin, J.-H. Complete genome sequence of Pseudomonas rhizosphaerae IH5T (= DSM 16299T), a phosphate-solubilizing rhizobacterium for bacterial biofertilizer. J. Biotechnol. 2015, 193, 137-138.

(49) Liu, X.; Jiang, X.; He, X.; Zhao, W.; Cao, Y.; Guo, T.; Li, T.; Ni, H.; Tang, X. Phosphatesolubilizing Pseudomonas sp. strain P34-L promotes wheat growth by colonizing the wheat rhizosphere and improving the wheat root system and soil phosphorus nutritional status. J. Plant Growth Regul. 2019, 38 (4), 1314-1324.

(50) Leclercq, S. O.; Wang, C.; Sui, Z.; Wu, H.; Zhu, B.; Deng, Y.; Feng, J. A multiplayer game: species of Clostridium, Acinetobacter, and Pseudomonas are responsible for the persistence of antibiotic resistance genes in manure-treated soils. Environ. Microbiol. 2016, 18(10), 3494-3508.

(51) Wang, N.; Yang, X.; Jiao, S.; Zhang, J.; Ye, B.; Gao, S. Sulfonamide-resistant bacteria and their resistance genes in soils fertilized with manures from Jiangsu Province, Southeastern China. PLoS One 2014, 9 (11), No. e112626.

(52) Van Bruggen, A.; Francis, I.; Jochimsen, K. Non-pathogenic rhizosphere bacteria belonging to the genera Rhizorhapis and Sphingobium provide specific control of lettuce corky root disease caused by species of the same bacterial genera. Plant Pathol. 2014, 63(6), 1384-1394.

(53) Baral, D.; Dvorak, B. I.; Admiraal, D.; Jia, S.; Zhang, C.; Li, X. Tracking the sources of antibiotic resistance genes in an urban stream during wet weather using shotgun metagenomic analyses. Environ. Sci. Technol. 2018, 52 (16), 9033-9044.

(54) Pu, Q.; Zhao, L.-X.; Li, Y.-T.; Su, J.-Q. Manure fertilization increase antibiotic resistance in soils from typical greenhouse vegetable production bases, China. J. Hazard. Mater. 2020, 391, 122267. 


\section{Supplementary Information}

Transmission Routes of Microbiome and Resistome from Manure to Soil and Lettuce

Yuepeng Sun, ${ }^{\dagger}$ Daniel Snow, ${ }^{\dagger}$ Harkamal Walia,${ }^{\S} \mathrm{Xu} \mathrm{Li}^{*}{ }^{*} \dagger$

†Department of Civil and Environmental Engineering, University of Nebraska-Lincoln, Lincoln,

Nebraska 68588, USA

Nebraska Water Center, University of Nebraska-Lincoln, Lincoln, Nebraska 68588, USA

${ }^{\S}$ Department of Agronomy and Horticulture, University of Nebraska-Lincoln, Lincoln, Nebraska 68583, USA

*Corresponding author

*Xu Li

Department of Civil and Environmental Engineering

University of Nebraska - Lincoln

900 N. 16th St, W150D Nebraska Hall

Lincoln, NE 68588-0531

Email: xuli@unl.edu

Total Number of Pages: 17

Total Number of Tables: 7

Total Number of Figures: 7 


\section{RESULTS}

\section{Alpha diversity of microbiome}

Alpha diversity indexes for microbiome varied across sample types, with significantly lower (ANOVA and Turkey's HSD, $p$ values $<0.05$ ) average number of genera and Shannon index in root $(7-15$ and $1.29-1.44$, respectively) and endosphere $(2-4$ and $0.63-0.81)$ than those in other sample types, such as surface soil (40 - 58 and 2.48 - 3.11, Table S3). ANOVA tests show that the manure treatment factor had no significant impacts on the alpha diversity indexes of the microbiomes (Table S4). In comparison, ANOVA tests show that sample type had significant impacts on the alpha diversity indexes of the microbiomes (Table S3 and S4).

\section{Alpha diversity of resistome}

A total of 359 ARG types were detected, with the average number ranging $21-145$ for each sample type (Table S6). Two-way ANOVA indicates significant differences in the number of ARG types across different sample types $(p$ values $<0.05)$ and treatment scenarios (Table $\mathbf{S 7}, p$ values $<0.05)$. Manure treatment had significant effects on the Shannon index and the number of ARG types in surface soil and episphere (Table S6). For example, manure application (T5 and T10) caused the detection of sulfonamide (e.g., sul1 and sul2) and tetracycline resistance genes (e.g., tet( $\mathrm{A})$ and $\operatorname{tet}(\mathrm{X}))$ in surface soil and episphere, while these ARGs were not detected in the original soil (Figure S5).

Compared to control, T10 had a significantly higher (t-test, $p$ values $<0.05$ ) number of shared ARGs between surface soil and episphere, and among endosphere, rhizosphere and root (Figure S6); T5 had a significant higher (t-test, $p<0.05)$ number of shared ARGs between surface soil and episphere (Figure S6A). These results imply the pivotal role of manure 
application in modulating resistome composition (especially in surface soil, episphere and endosphere samples) and transmission from manured soil to lettuce. 
Table S1. Overall sampling scheme.

\begin{tabular}{lllll}
\hline Sample type & Treatment & $\begin{array}{l}\text { Sampling } \\
\text { time }\end{array}$ & $\begin{array}{l}\text { Sampling } \\
\text { location }\end{array}$ & $\begin{array}{l}\text { \# of replicates per } \\
\text { combination }\end{array}$ \\
\hline Soil & & Week 0 & & 3 replicates \\
\hline Manure & & Week 0 & & 3 replicates \\
\hline \multirow{2}{*}{ Surface soil } & C, T5, T10 & Week 1 (W1) & & 3 pooled replicates \\
& C, T5, T10 & Week 3 (W3) & & 3 pooled replicates \\
& $\mathrm{C}, \mathrm{T} 5, \mathrm{~T} 10$ & Week 6 (W6) & & 3 pooled replicates \\
\hline \multirow{2}{*}{ Rhizosphere } & $\mathrm{C}, \mathrm{T} 5, \mathrm{~T} 10$ & Week 6 & Top (T) & 3 pooled replicates \\
soil & $\mathrm{C}, \mathrm{T} 5, \mathrm{~T} 10$ & Week 6 & Middle (M) & 3 pooled replicates \\
& $\mathrm{C}, \mathrm{T} 5, \mathrm{~T} 10$ & Week 6 & Bottom (B) & 3 pooled replicates \\
\hline Root & $\mathrm{C}, \mathrm{T} 5, \mathrm{~T} 10$ & Week 6 & & 3 pooled replicates \\
\hline Episphere & $\mathrm{C}, \mathrm{T} 5, \mathrm{~T} 10$ & Week 6 & & 3 pooled replicates \\
\hline Endosphere & $\mathrm{C}, \mathrm{T} 5, \mathrm{~T} 10$ & Week 6 & & 3 pooled replicates \\
\hline
\end{tabular}


Table S2. Total reads and trimmed reads for shotgun metagenomic sequencing.

\begin{tabular}{|c|c|c|c|c|c|c|c|c|c|}
\hline \multirow[t]{3}{*}{ Sample type } & \multirow[t]{3}{*}{ Treatment } & \multirow{3}{*}{$\begin{array}{l}\text { Sampling } \\
\text { Time }\end{array}$} & \multirow{3}{*}{$\begin{array}{l}\text { Sampling } \\
\text { location }\end{array}$} & \multicolumn{6}{|c|}{ Round } \\
\hline & & & & \multicolumn{2}{|l|}{1} & \multicolumn{2}{|c|}{2} & \multicolumn{2}{|c|}{3} \\
\hline & & & & $\begin{array}{c}\text { Total reads } \\
\times 2 \\
\end{array}$ & $\begin{array}{l}\text { Trimmed } \\
\text { reads } \times 2\end{array}$ & $\begin{array}{c}\text { Total } \\
\text { reads } \times 2\end{array}$ & $\begin{array}{l}\text { Trimmed } \\
\text { reads } \times 2\end{array}$ & $\begin{array}{c}\text { Total } \\
\text { reads } \times 2\end{array}$ & $\begin{array}{l}\text { Trimmed } \\
\text { reads } \times 2\end{array}$ \\
\hline Soil & & W0 & & 16935474 & 16523066 & 22255771 & 21075470 & 18712521 & 18398870 \\
\hline Manure & & W0 & & 14562266 & 14250739 & 23675425 & 23028860 & 24931240 & 24435344 \\
\hline \multirow{9}{*}{ Surface soil } & $\mathrm{C}$ & W1 & & 25808954 & 25694705 & 21274749 & 20577005 & 19494638 & 19091880 \\
\hline & & W3 & & 18461872 & 17760637 & 32363833 & 30742031 & 20961219 & 20494428 \\
\hline & & W6 & & 18383498 & 17872941 & 21551647 & 20652821 & 28538760 & 27690754 \\
\hline & T5 & W1 & & 28298479 & 27479742 & 21315840 & 20652821 & 15761754 & 15470069 \\
\hline & & W3 & & 17079039 & 16799841 & 17646825 & 17274068 & 18905149 & 18509825 \\
\hline & & W6 & & 19722875 & 19228899 & 25048543 & 24150337 & 29086141 & 28244532 \\
\hline & T10 & W1 & & 15923384 & 15617345 & 22035976 & 21357693 & 21382195 & 20929791 \\
\hline & & W3 & & 30335850 & 29542821 & 24248108 & 23587006 & 28785181 & 28072923 \\
\hline & & W6 & & 20825475 & 20239646 & 37529771 & 35733904 & 20380093 & 19969219 \\
\hline \multirow{9}{*}{$\begin{array}{l}\text { Rhizosphere } \\
\text { soil }\end{array}$} & $\mathrm{C}$ & W6 & $\mathrm{T}$ & 17093537 & 16779841 & 23951738 & 22789792 & 19848363 & 19412445 \\
\hline & & & M & 24321049 & 23490165 & 31939959 & 30448574 & 19657877 & 19205181 \\
\hline & & & $\mathrm{B}$ & 20001952 & 19503312 & 25891618 & 24497597 & 21013741 & 20388738 \\
\hline & T5 & & $\mathrm{T}$ & 20255196 & 19746318 & 20167674 & 19741777 & 29064444 & 28209725 \\
\hline & & & M & 19735775 & 19218269 & 31785831 & 30270390 & 40032608 & 38728078 \\
\hline & & & B & 24079488 & 23380364 & 19939361 & 19133978 & 15720659 & 15451562 \\
\hline & $\mathrm{T} 10$ & & $\mathrm{~T}$ & 22361166 & 21605414 & 37139566 & 35836685 & 25376247 & 24779814 \\
\hline & & & M & 24739753 & 23891261 & 22665021 & 21779661 & 23032153 & 22359571 \\
\hline & & & $\mathrm{B}$ & 25440600 & 24405457 & 20244211 & 19502000 & 21774836 & 21257240 \\
\hline \multirow[t]{3}{*}{ Root } & $\mathrm{C}$ & W6 & & 18974274 & 18041989 & 18869812 & 18058139 & 27977283 & 26564217 \\
\hline & $\mathrm{T} 5$ & & & 12217629 & 11865603 & 27431727 & 25866078 & 21087159 & 20167839 \\
\hline & $\mathrm{T} 10$ & & & 15122307 & 14568416 & 30173319 & 28436839 & 21859894 & 20907222 \\
\hline \multirow[t]{3}{*}{ Episphere } & $\mathrm{C}$ & W6 & & 17652359 & 16993401 & 21471307 & 21025417 & 17027900 & 16733055 \\
\hline & T5 & & & 12204532 & 11857844 & 24303575 & 23699086 & 16679820 & 16368401 \\
\hline & $\mathrm{T} 10$ & & & 19425250 & 18517271 & 31000122 & 30099358 & 42313842 & 40830779 \\
\hline \multirow[t]{3}{*}{ Endosphere } & $\mathrm{C}$ & W6 & & 25593188 & 24777294 & 17178884 & 16669714 & 22205485 & 21422488 \\
\hline & $\mathrm{T} 5$ & & & 12400938 & 12127887 & 16155839 & 15481786 & 14067593 & 13744787 \\
\hline & $\mathrm{T} 10$ & & & 19522061 & 18986575 & 15068954 & 14686058 & 13326235 & 13002836 \\
\hline
\end{tabular}


Table S3. The alpha diversity, Shannon Index and the number of genera, of the microbiome in various sample types.

\begin{tabular}{|c|c|c|c|c|}
\hline Sample type & Treatment & Time/Location & Shannon index & Number of Genera \\
\hline Soil & & Week 0 & $2.75 \pm 0.33$ & $38 \pm 8$ \\
\hline Manure & & Week 0 & $2.51 \pm 0.54$ & $50 \pm 6$ \\
\hline \multirow{9}{*}{ Surface soil } & \multirow{3}{*}{$\mathrm{C}$} & Week 1 & $2.84 \pm 0.08$ & $40 \pm 5$ \\
\hline & & Week 3 & $2.75 \pm 0.37$ & $51 \pm 5$ \\
\hline & & Week 6 & $3.06 \pm 0.40$ & $56 \pm 19$ \\
\hline & \multirow{3}{*}{ T5 } & Week 1 & $2.55 \pm 0.06$ & $50 \pm 7$ \\
\hline & & Week 3 & $2.38 \pm 0.29$ & $40 \pm 10$ \\
\hline & & Week 6 & $3.11 \pm 0.29$ & $55 \pm 8$ \\
\hline & \multirow{3}{*}{$\mathrm{T} 10$} & Week 1 & $2.48 \pm 0.15$ & $47 \pm 1$ \\
\hline & & Week 3 & $2.80 \pm 0.23$ & $58 \pm 9$ \\
\hline & & Week 6 & $2.81 \pm 0.17$ & $48 \pm 2$ \\
\hline \multirow{9}{*}{$\begin{array}{l}\text { Rhizosphere } \\
\text { soil }\end{array}$} & \multirow{3}{*}{$\mathrm{C}$} & Bottom & $2.97 \pm 0.21$ & $47 \pm 15$ \\
\hline & & Middle & $3.04 \pm 0.11$ & $47 \pm 2$ \\
\hline & & Top & $2.75 \pm 0.52$ & $43 \pm 6$ \\
\hline & \multirow{3}{*}{ T5 } & Bottom & $3.19 \pm 0.13$ & $53 \pm 13$ \\
\hline & & Middle & $3.14 \pm 0.20$ & $50 \pm 11$ \\
\hline & & Top & $2.64 \pm 0.75$ & $53 \pm 12$ \\
\hline & \multirow{3}{*}{$\mathrm{T} 10$} & Bottom & $2.83 \pm 0.45$ & $49 \pm 12$ \\
\hline & & Middle & $2.97 \pm 0.06$ & $47 \pm 14$ \\
\hline & & Top & $3.12 \pm 0.16$ & $55 \pm 5$ \\
\hline \multirow{3}{*}{ Root } & $\mathrm{C}$ & Week 6 & $1.41 \pm 0.64$ & $15 \pm 4$ \\
\hline & T5 & Week 6 & $1.29 \pm 0.26$ & $9 \pm 4$ \\
\hline & $\mathrm{T} 10$ & Week 6 & $1.44 \pm 0.59$ & $7 \pm 4$ \\
\hline \multirow{3}{*}{ Episphere } & $\mathrm{C}$ & Week 6 & $1.82 \pm 0.26$ & $44 \pm 4$ \\
\hline & T5 & Week 6 & $2.29 \pm 0.81$ & $49 \pm 6$ \\
\hline & $\mathrm{T} 10$ & Week 6 & $2.34 \pm 0.74$ & $50 \pm 9$ \\
\hline \multirow{3}{*}{ Endosphere } & $\mathrm{C}$ & Week 6 & $0.63 \pm 0.16$ & $2 \pm 1$ \\
\hline & $\mathrm{T} 5$ & Week 6 & $0.68 \pm 0.48$ & $2 \pm 1$ \\
\hline & $\mathrm{T} 10$ & Week 6 & $0.81 \pm 0.34$ & $4 \pm 2$ \\
\hline
\end{tabular}


Table S4. The $p$ and F values of the two-way ANOVA analyses, on manure treatment and sample type, for the alpha diversity indexes of the microbiome at the genus level.

\begin{tabular}{lcccc}
\hline \multirow{2}{*}{ Factors } & \multicolumn{2}{c}{ Number of Genera } & \multicolumn{2}{c}{ Shannon index } \\
\cline { 2 - 5 } & $\boldsymbol{p}$ value & F value & $\boldsymbol{p}$ value & F value \\
\hline Manure Treatment & 0.701 & 0.357 & 0.677 & 0.407 \\
Sample Type & $<2 \mathrm{e}-16$ & 68.515 & $<2 \mathrm{e}-16$ & 52.615 \\
Treatment $\times$ Type & 0.929 & 0.377 & 0.918 & 0.667 \\
\hline
\end{tabular}


Table S5. The $p$-values from the ANOVA analyses on ARG abundance among sample types, treatments, sampling times, sampling locations. Significance is indicated by asterisks, with $p<0.05, p<0.01$ and $p<0.001$ indicated by $* * *$ and $* * *$, respectively. For surface soil samples, manure treatment was defined as main treatment while time as a repeated-measure.

\begin{tabular}{|c|c|c|c|c|c|c|c|c|}
\hline \multirow{2}{*}{ ARG family } & \multicolumn{2}{|c|}{ Surface Soil } & \multicolumn{2}{|c|}{ Rhizosphere soil } & \multirow{2}{*}{$\begin{array}{l}\text { Root } \\
\text { Treatment }\end{array}$} & \multirow{2}{*}{$\begin{array}{l}\text { Episphere } \\
\text { Treatment }\end{array}$} & \multirow{2}{*}{$\begin{array}{l}\text { Endosphere } \\
\text { Treatment }\end{array}$} & \multirow{2}{*}{ Sample Type } \\
\hline & Treatment & Time & Treatment & Location & & & & \\
\hline aminoglycoside & $0.009 *$ & 0.2360 & 0.1240 & $0.0198 *$ & 0.6870 & 0.7760 & 0.5730 & $1.96 \mathrm{e}-07 * * *$ \\
\hline bacitracin & 0.2790 & 0.3790 & 0.5840 & 0.6580 & 0.3330 & 0.5260 & $0.0438 *$ & $0.0001 * * *$ \\
\hline carbomycin & 0.1660 & 0.5170 & 0.0844 & 0.0819 & & 0.4220 & & 0.1690 \\
\hline chloramphenicol & $0.006 *$ & 0.3700 & 0.2402 & $0.0033 * *$ & 0.5990 & 0.4520 & 0.5950 & $2.56 \mathrm{e}-07 * * *$ \\
\hline fosfomycin & 0.1840 & 0.6240 & 0.6140 & 0.3420 & 0.7150 & 0.3950 & & 0.0957 \\
\hline fosmidomycin & $0.029 *$ & 0.0949 & 0.2171 & $0.00789 * *$ & 0.4400 & 0.9570 & $0.0246 *$ & $3.93 \mathrm{e}-14 * * *$ \\
\hline kasugamycin & 0.8710 & 0.2110 & 0.9660 & 0.6590 & 0.6290 & 0.4470 & & $1.05 \mathrm{e}-06 * * *$ \\
\hline MLS & $0.015 *$ & 0.2760 & 0.1470 & 0.9840 & 0.2720 & 0.3130 & 0.6100 & $<2 \mathrm{e}-16 * * *$ \\
\hline multidrug & 0.4180 & 0.3360 & 0.9030 & 0.3850 & 0.3500 & 0.3330 & 0.1800 & $0.0004 * * *$ \\
\hline polymyxin & 0.1560 & 0.2922 & 0.7564 & 0.0557 & & 0.3260 & 0.4420 & 0.4560 \\
\hline puromycin & 0.0788 & 0.4150 & 0.3600 & 0.6780 & 0.2760 & 0.4560 & & $0.0327 *$ \\
\hline quinolone & 0.3500 & 0.5310 & 0.2020 & 0.2280 & 0.4990 & 0.3940 & 0.4420 & $5.21 \mathrm{e}-07 * * *$ \\
\hline rifamycin & $0.0296 *$ & 0.8310 & 0.7590 & 0.0126 * & 0.4450 & 0.7870 & $0.0490 *$ & $1.65 \mathrm{e}-09 * * *$ \\
\hline sulfonamide & $0.0003 * *$ & 0.5360 & $0.0200 *$ & $0.0185 *$ & 0.5350 & 0.5290 & 0.5760 & $3.98 \mathrm{e}-09 * * *$ \\
\hline tetracycline & $0.0143 *$ & $0.0290 \%$ & 0.5050 & 0.9510 & 0.7060 & 0.6280 & 0.5530 & $1.23 \mathrm{e}-05 * * *$ \\
\hline vancomycin & 0.0643 & 0.1700 & 0.4370 & 0.1380 & 0.9220 & 0.6370 & 0.8860 & $0.0038 * *$ \\
\hline trimethoprim & 0.1160 & 0.8040 & 0.4020 & 0.5910 & & 0.4020 & & $1.09 \mathrm{e}-05 * * *$ \\
\hline tetracenomycin $\mathrm{C}$ & 0.4410 & 0.3070 & 0.7400 & 0.9540 & 0.4570 & 0.7300 & 0.4220 & $0.0168 *$ \\
\hline total & 0.4900 & 0.2420 & 0.7730 & 0.8510 & 0.3200 & 0.5850 & 0.2110 & $7.84 \mathrm{e}-10 * * *$ \\
\hline
\end{tabular}


Table S6. The alpha diversity, Shannon Index and the number of ARGs, of the resistome in various sample types. Items with different letters represent significant differences at the $p<0.05$ level according to Tukey's HSD tests.

\begin{tabular}{|c|c|c|c|c|c|}
\hline Sample type & Treatment & Time/Location & Shannon index & \multicolumn{2}{|c|}{ Number of ARGs } \\
\hline Soil & & Week 0 & $2.72 \pm 0.33$ & \multicolumn{2}{|l|}{$75 \pm 8$} \\
\hline Manure & & Week 0 & $3.79 \pm 0.09$ & \multicolumn{2}{|l|}{$145 \pm 9$} \\
\hline \multirow{9}{*}{ Surface soil } & \multirow{3}{*}{$\mathrm{C}$} & Week 1 & $2.92 \pm 0.27$ & $88 \pm 3$ & \multirow{4}{*}{$\mathbf{a}$} \\
\hline & & Week 3 & $3.19 \pm 0.17$ & $103 \pm 5$ & \\
\hline & & Week 6 & $3.24 \pm 0.10$ & $105 \pm 19$ & \\
\hline & \multirow{3}{*}{ T5 } & Week 1 & $3.76 \pm 0.13$ & $137 \pm 21$ & \\
\hline & & Week 3 & $3.39 \pm 0.16$ & $102 \pm 9$ & \multirow[t]{3}{*}{ b } \\
\hline & & Week 6 & $3.47 \pm 0.09$ & $111 \pm 2$ & \\
\hline & \multirow{3}{*}{$\mathrm{T} 10$} & Week 1 & $3.74 \pm 0.07$ & $127 \pm 9$ & \\
\hline & & Week 3 & $3.56 \pm 0.10$ & $130 \pm 17$ & \multirow[t]{2}{*}{ b } \\
\hline & & Week 6 & $3.51 \pm 0.13$ & $110 \pm 15$ & \\
\hline \multirow{9}{*}{$\begin{array}{l}\text { Rhizosphere } \\
\text { soil }\end{array}$} & \multirow{3}{*}{$\mathrm{C}$} & Bottom & $3.09 \pm 0.16$ & \multicolumn{2}{|l|}{$83 \pm 4$} \\
\hline & & Middle & $3.04 \pm 0.21$ & $90 \pm 8$ & $90 \pm 8$ \\
\hline & & Top & $3.20 \pm 0.09$ & $89 \pm 17$ & \\
\hline & \multirow{3}{*}{ T5 } & Bottom & $3.02 \pm 0.12$ & \multicolumn{2}{|l|}{$85 \pm 6$} \\
\hline & & Middle & $3.10 \pm 0.12$ & \multicolumn{2}{|l|}{$93 \pm 10$} \\
\hline & & Top & $3.34 \pm 0.05$ & \multicolumn{2}{|l|}{$105 \pm 15$} \\
\hline & \multirow{3}{*}{$\mathrm{T} 10$} & Bottom & $3.24 \pm 0.13$ & \multicolumn{2}{|l|}{$93 \pm 17$} \\
\hline & & Middle & $3.12 \pm 0.07$ & \multicolumn{2}{|l|}{$89 \pm 11$} \\
\hline & & Top & $3.35 \pm 0.08$ & \multicolumn{2}{|l|}{$107 \pm 5$} \\
\hline \multirow{3}{*}{ Root } & $\mathrm{C}$ & Week 6 & $3.14 \pm 0.23$ & \multicolumn{2}{|l|}{$45 \pm 15$} \\
\hline & T5 & Week 6 & $2.97 \pm 0.11$ & \multicolumn{2}{|l|}{$35 \pm 11$} \\
\hline & $\mathrm{T} 10$ & Week 6 & $3.17 \pm 0.48$ & \multicolumn{2}{|l|}{$39 \pm 16$} \\
\hline & $\mathrm{C}$ & Week 6 & $3.10 \pm 0.31$ & $93 \pm 15 \mathbf{a}$ & \\
\hline Episphere & T5 & Week 6 & $3.72 \pm 0.28$ & $123 \pm 11$ & \\
\hline & $\mathrm{T} 10$ & Week 6 & $3.62 \pm 0.07$ & $134 \pm 4 \mathbf{b}$ & \\
\hline & $\mathrm{C}$ & Week 6 & $2.77 \pm 0.10$ & $21 \pm 2$ & \\
\hline Endosphere & T5 & Week 6 & $2.84 \pm 0.18$ & $23 \pm 4$ & \\
\hline & $\mathrm{T} 10$ & Week 6 & $2.83 \pm 0.11$ & $24 \pm 4$ & \\
\hline
\end{tabular}


Table S7. The $p$ and $\mathrm{F}$ values of the two-way ANOVA analyses, on manure treatment and sample type, for the alpha diversity indexes of the resistome at the ARG level.

\begin{tabular}{lcccc}
\hline Factors & \multicolumn{2}{c}{ Number of ARGs } & \multicolumn{2}{c}{ Shannon index } \\
\cline { 2 - 5 } & $\boldsymbol{p}$ value & F value & $\boldsymbol{p}$ value & F value \\
\hline Treatment & 0.00443 & 5.855 & $8.81 \mathrm{e}-05$ & 10.680 \\
Sample Type & $<2 \mathrm{e}-16$ & 67.714 & $1.04 \mathrm{e}-11$ & 16.317 \\
Treatment*Type & 0.03115 & 2.368 & 0.0156 & 2.695 \\
\hline
\end{tabular}




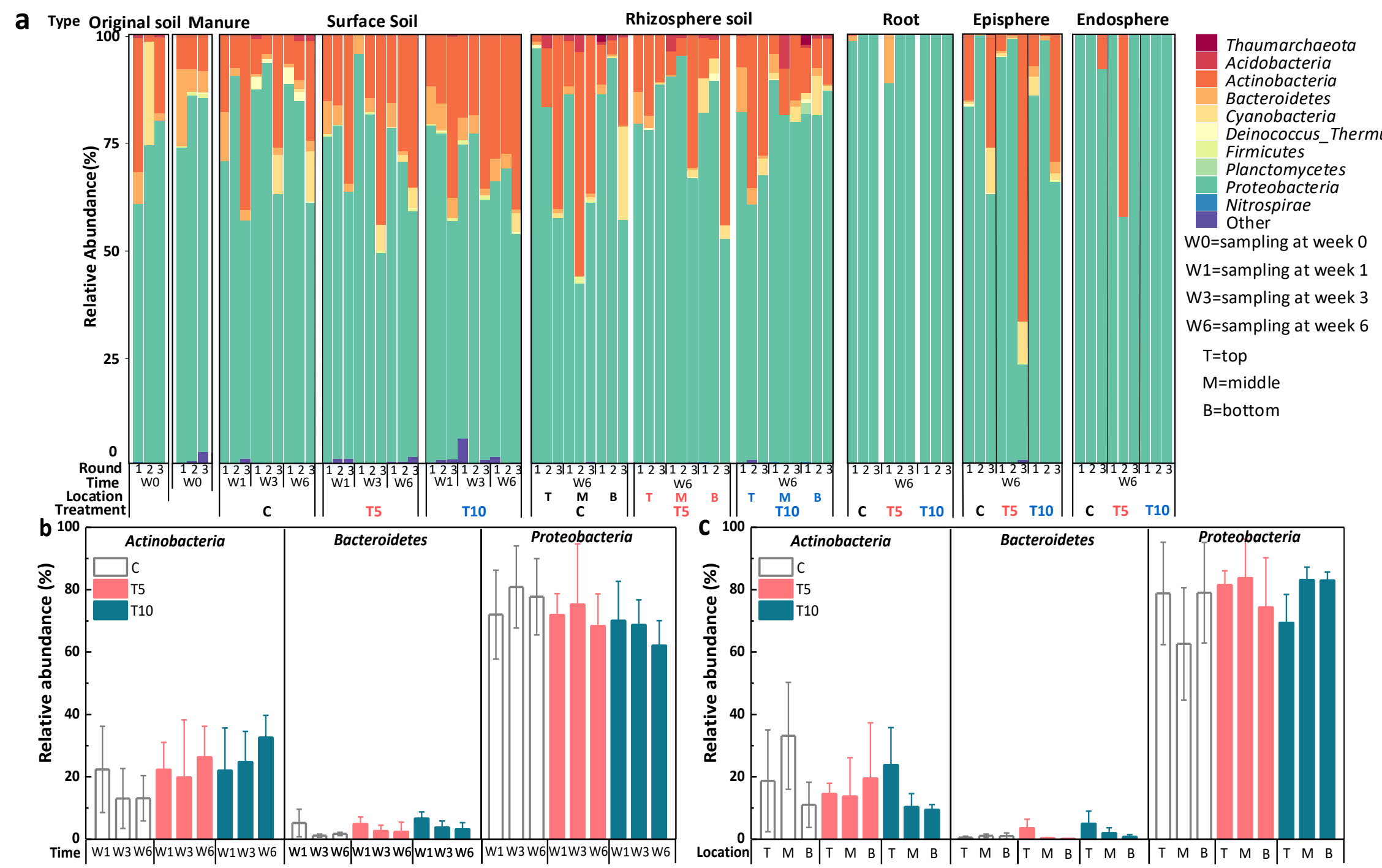

Figure S1. Relative abundance of phyla in different sample types (a), dynamic change of major phyla in surface soil at three sampling times (b), and spatial variations of major phyla in rhizosphere soil (c). Error bars indicate standard deviation $(n=3)$. 

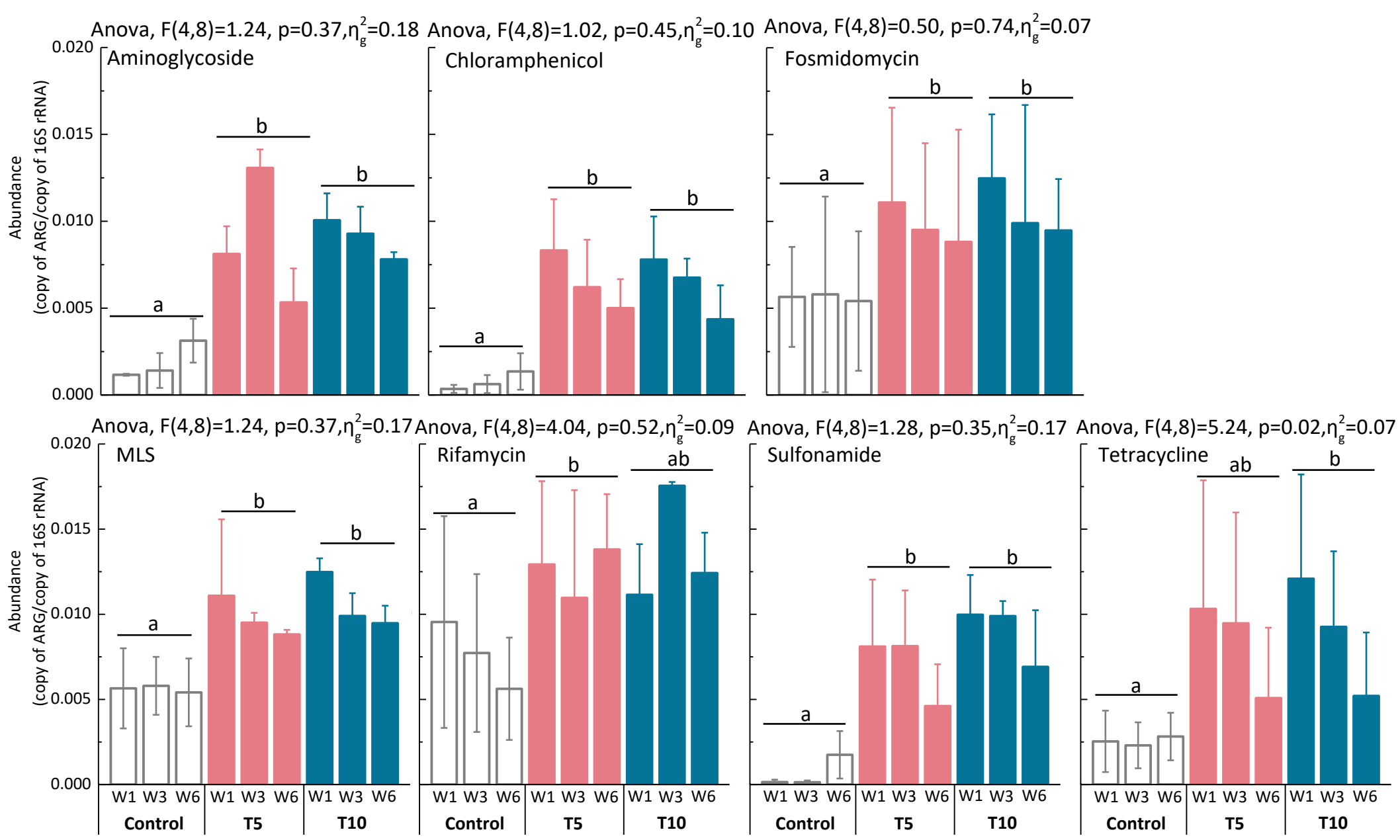

Figure S2. Abundance of ARG families in surface soil that were significantly impacted by manure treatment. Different letters represent significant differences according to Tukey's HSD at $p<0.05$. Two-way interactions between treatment and time on the abundance of ARG families are shown. Error bars represent standard deviations $(n=3)$. 

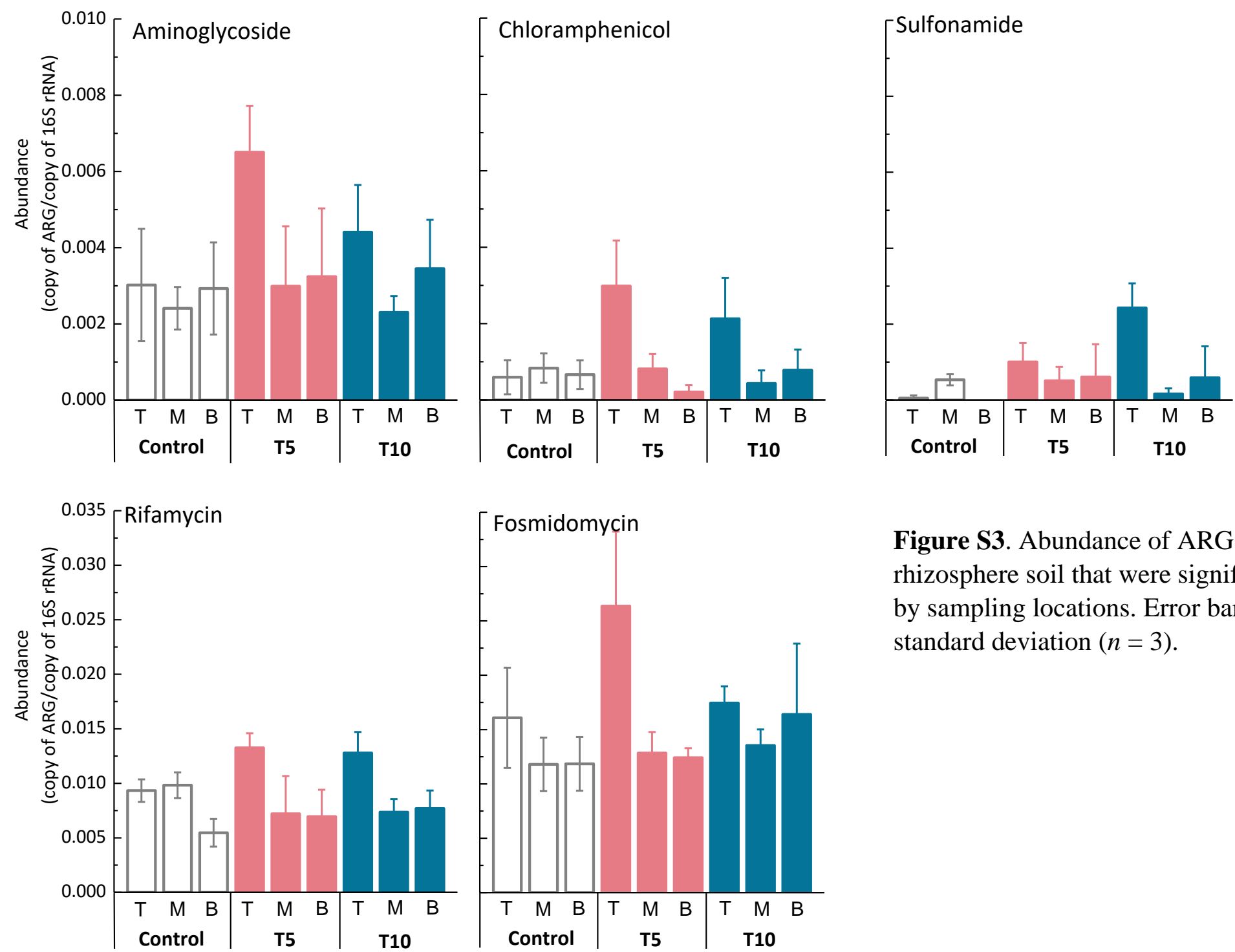

Figure S3. Abundance of ARG families in rhizosphere soil that were significantly impacted by sampling locations. Error bars indicate standard deviation $(n=3)$. 


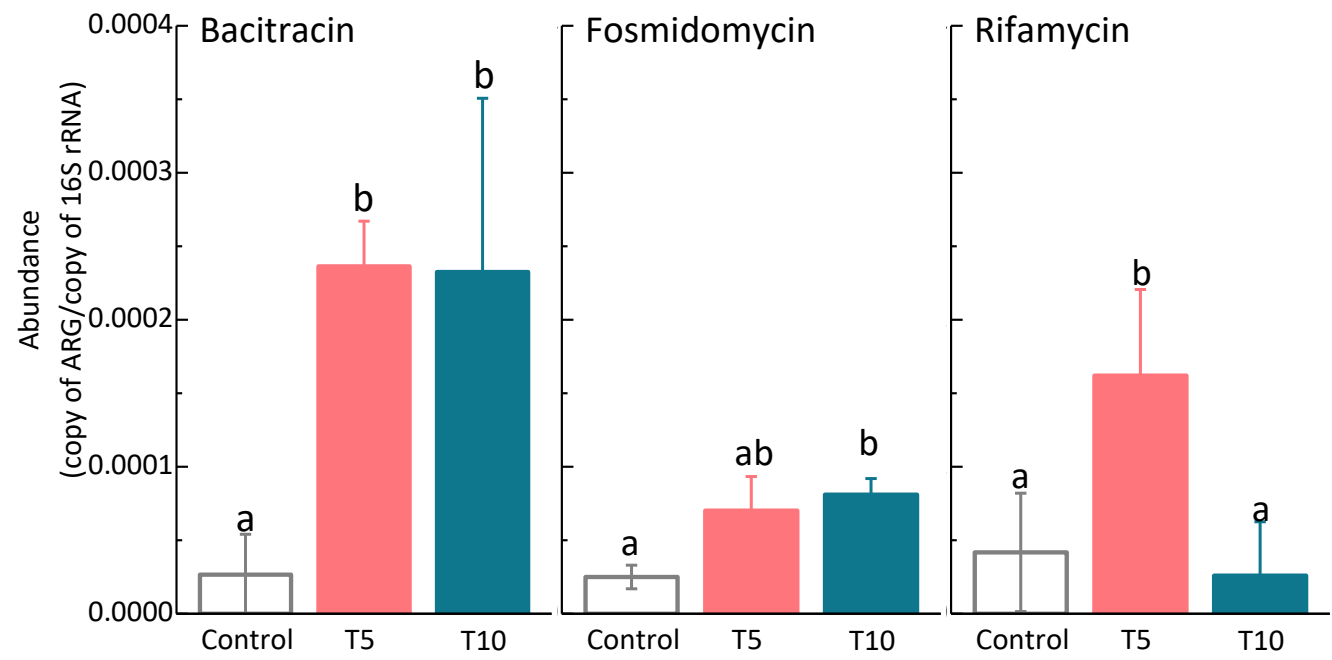

Figure S4. Abundance of ARG families in endosphere that were significantly impacted by manure treatment. Column with different letter indicates significant difference according to Tukey's HSD with $p<0.05$. Error bars indicate standard deviation $(n=3)$. 


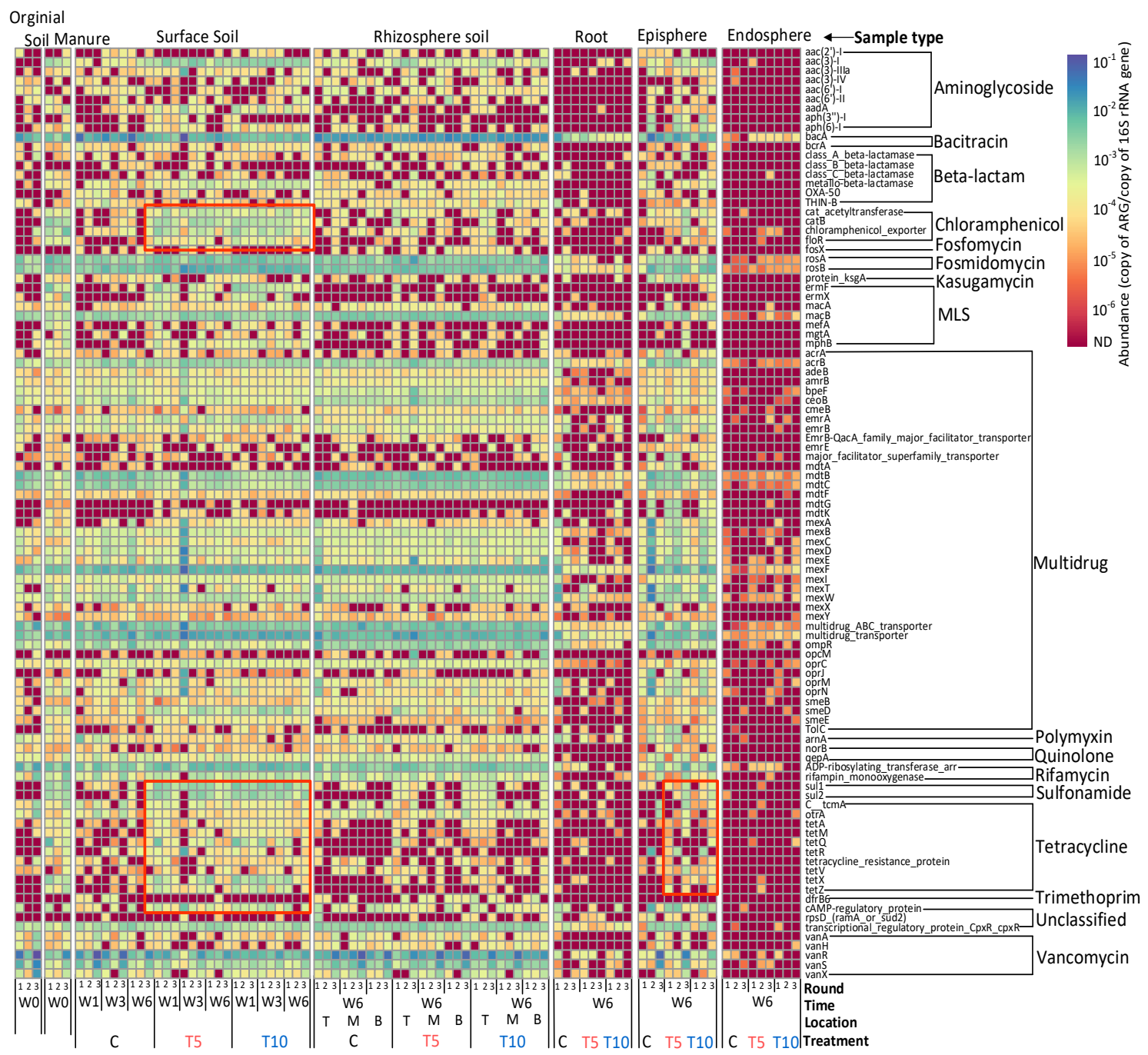

Figure S5. Abundance of the top 100 ARGs (i.e., average abundance higher than $10^{-5}$ copy of ARG per copy of the 16S rRNA gene across all samples) among different sample types and treatments. Red frames represent genes detected following manure application. 

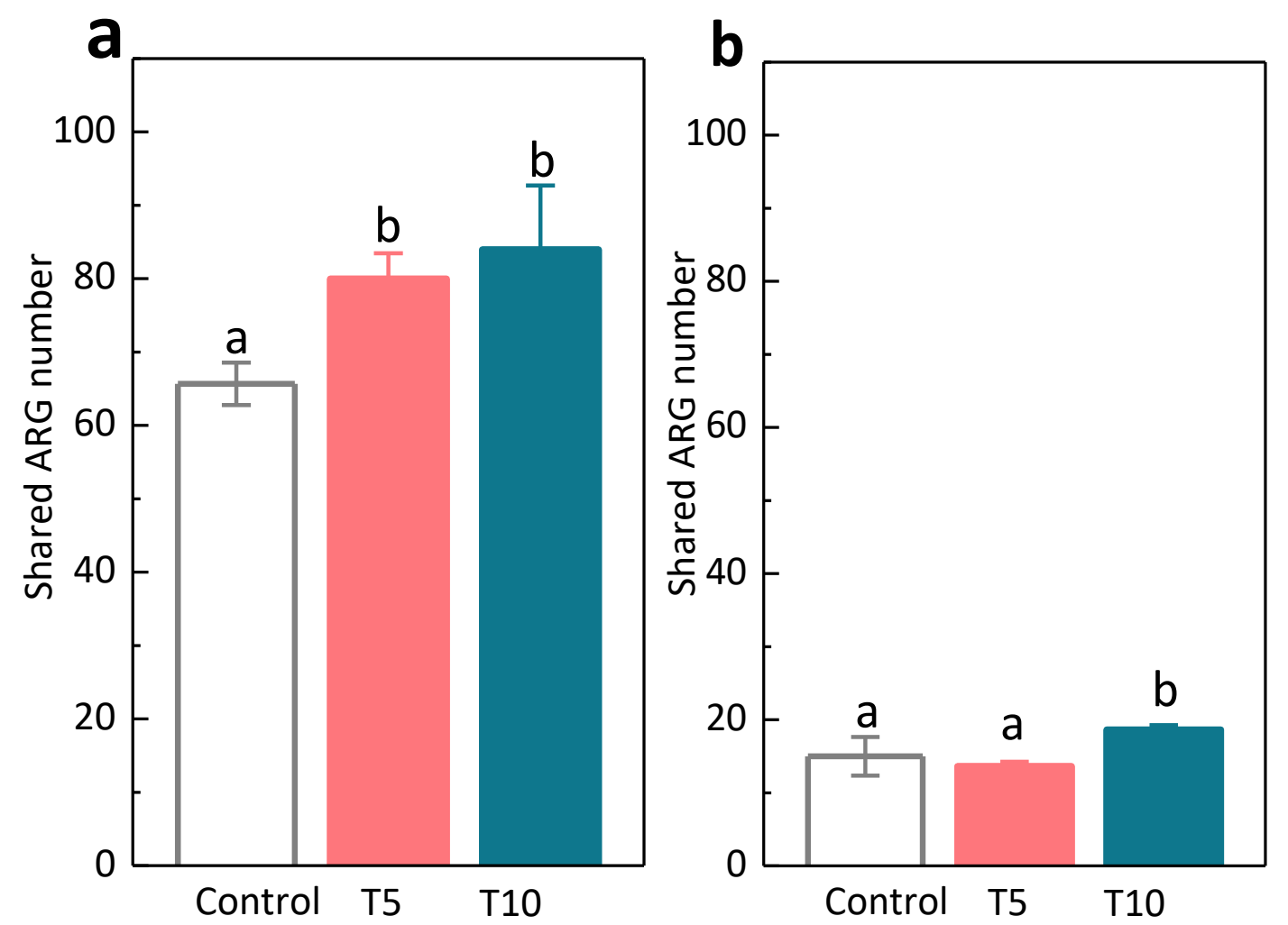

Figure S6. Numbers of ARGs shared between surface soil and episphere (A), and shared among endosphere, rhizosphere soil, and root (B). Column with different letters indicate significant difference $(t$-test, $p<0.05)$. Error bars indicate standard deviation $(n=3)$. 

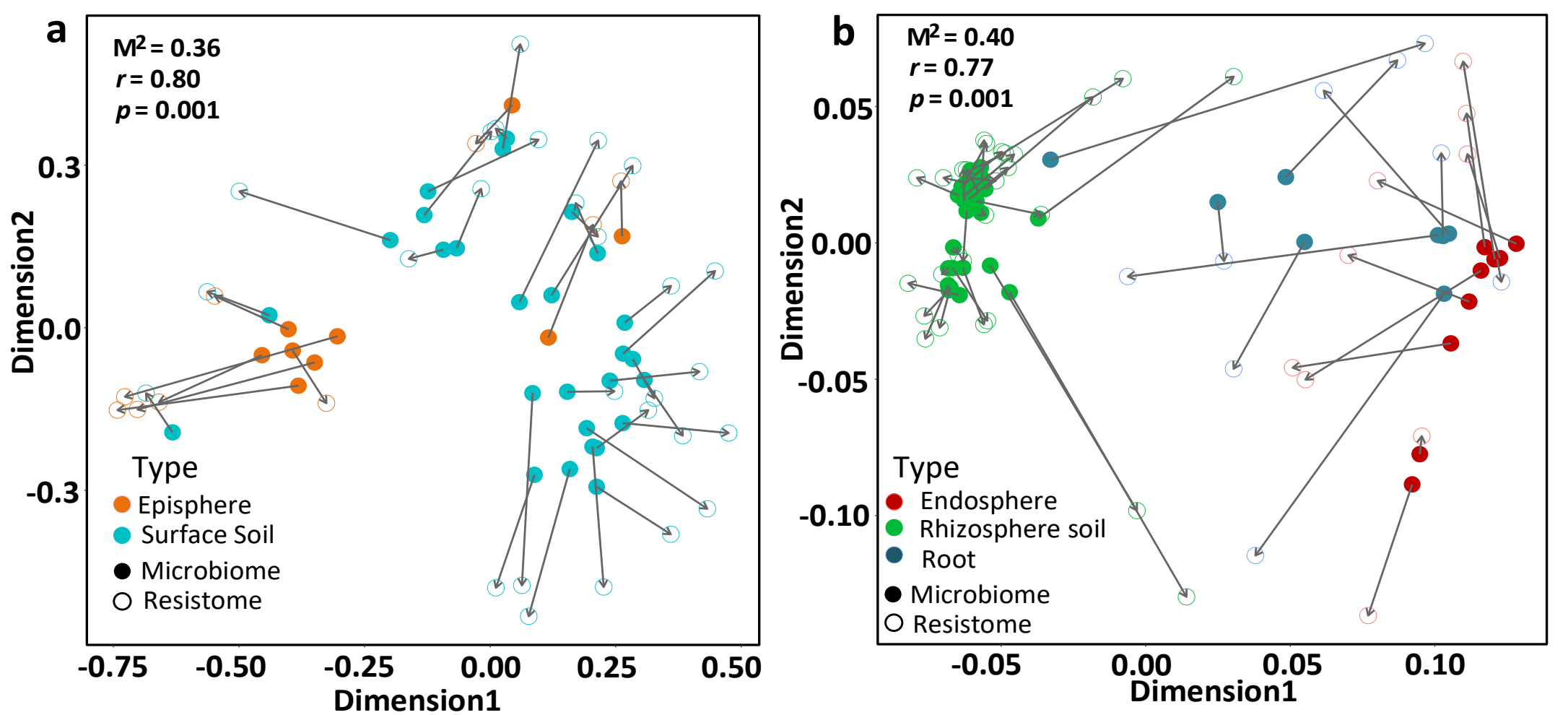

Figure S7. Procrustes test depicting the significant correlations between resistomes and microbiomes of surface soil and episphere (a), and of rhizosphere soil, root, and endosphere (b). Bray-Curtis distance with 9999 permutations were applied. 